\title{
ASPECTOS DA DINÂMICA DE UM FRAGMENTO FLORESTAL EM PIRACICABA-SP: SILVIGÊNESE E CICLAGEM DE NUTRIENTES
}

RENATA EVANGELISTA DE OLIVEIRA

Engenheira Florestal

Orientador: Prof. Dr. FÁBIO POGGIANI

Dissertação apresentada à Escola Superior de Agricultura "Luiz de Queiroz", Universidade de São Paulo, para obtenção do título de Mestre em Ciências, Área de Concentração: Ciências Florestais.

P I R A C I CA B A

Estado de São Paulo - Brasil

Agosto - 1997 
Dados Internacionais de Catalogação na Publicacão (CIP) DIVISÃO DE BIBLIOTECA E DOCUMENTAÇĀO - Campus "Luiz de Queiroz"/USP

Oliveira, Renata Evangelista de

Aspectos da dinàmica de um fragmento florestal em Piracicaba-SP : silvigênese $e$ ciclagem de nutrientes / Renata Evangelista de Oliveira. . Piracicaba, 1997.

80 p. : il

Dissertaçăo (mestrado) - Escola Superior de Agricultura Luiz de Queiroz, 1997.

Bibliografia.

1. Ciclo de nutriente 2. Clareira 3. Ecologia florestal 4. Floresta tropical 5. Piracicaba, SP I. Titulo

CDD 634.94 


\section{ASPECTOS DA DINÂMICA DE UM FRAGMENTO FLORESTAL EM PIRACICABA-SP: SILVIGÊNESE E CICLAGEM DE NUTRIENTES}

Aprovada em: 29/09/1997

Comissão Julgadora:

Prof. Dr. Fábio Poggiani

Prof. Dr. Ricardo Ribeiro Rodrigues

Prof. Dr. Waldir Mantovani
ESALQ/USP

ESALQ/USP

IB/USP

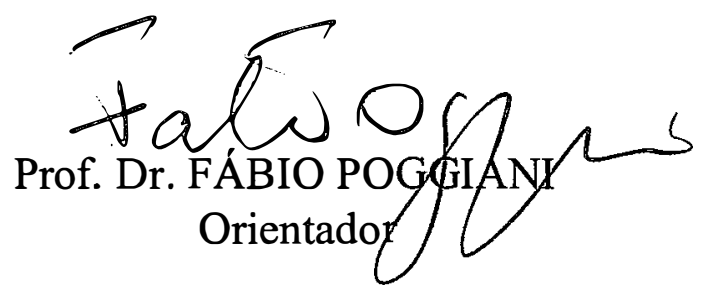


Dedico este trabalho:

À minha família, pela sensação de me sentir em casa, independente de onde estejamos, sempre que estamos juntos. Pelo apoio e pelo amor (imenso, indescritível, interminável) que me possibilitou cada um dos meus momentos.

Em especial ao Zague e à Eliéte, pelas noções de vida, lições de humanidade e exemplos de amor que sempre me acompanharam.

Aos meus irmãos Preto e Quequel, por termos dividido coisas tão especiais.

"Sua força me abriu caminhos..."

Ao João, melhor maridão do mundo, por nossa vida juntos- que a cada dia descubro ser mais maravilhosa- pelo apoio e incentivo em todos os momentos, pelo colo, pelo amor imenso e por me fazer feliz.

"O meu verso dá pulo e cambalhotas quando te vê, porque você é meu único e definitivo poema..."

A. Valença 


\section{AGRADECIMENTOS}

“Cada um de nós é um Universo..."

R. Seixas

Esse trabalho só foi possivel graças à união de muitas mãos e de muitas mentes. Agradeço a todos que, direta ou indiretamente contribuirram para a sua realização, em especial:

Ao meu orientador, Prof. Fábio Poggiani, pela orientação, por ter me possibilitado esses anos de aprendizado, pela amizade e pelo apoio, meus agradecimentos muito mais que especiais.

Ao João, por ser uma presença constante e pela grande e insubstituivel ajuda em todas as fases deste trabalho. Obrigadaço!

Ao Samir, meu "estatístico de plantão", pelas sugestões, pelas discussões, pelas "aulas" (e foram várias) e pela amizade.

Ao Girlei, meu "mini-orientador", por toda a ajuda, desde as primeiras idéias, execução e obtenção dos resultados desse trabalho com relação à Ciclagem de Nutrientes, até o "aluguel" de noites e fins de semana.

À Lili, pela valiosa colaboração no trabalho de Silvigênese, desde o campo até as longas horas brigando com o computador, pelos chás da tarde e por ser uma "mulher-exemplo".

Aos amigos que muito ajudaram na parte prática (trabalho escravo): Marli, Lili, Nero e (sempre) João. Agradecimentos especiais!

À grande amiga e mestra Vera Lex Engel, pelo incentivo à pós graduação, pelo apoio e amizade, pela leitura atenciosa e importantíssimas sugestões na elaboração da versão final deste trabalho. Finalmente, por ser uma referência, sempre, no que diz respeito à minha carreira profissional.

Aos professores Ricardo Ribeiro Rodrigues, João Luís Ferreira Batista e Waldir Mantovani pelas correções, questionamentos e valiosas sugestões ao trabalho. Sua ajuda foi gigantesca...

À minha irmã Guimba Cristina, por existir, pela convivência e amizade de muito tempo (Nossa, são nove anos...só nesta vida). Você é muito especial!!!

Às amigas Lili, Lau, Elisa, Rose e Guimba pelos tricôs intermináveis, e por tudo o que passamos juntas; seja no bar, mato ou cidade. 
À Lina (anjo ou buda?), pessoa especial que tive o grande privilégio de conhecer durante esses "anos de mestrado", e que se tornou uma grande e querida amiga.

À minha querida e inesquecível turma de Pós Graduação em Ciências Florestais, todos grandes amigos, grandes pessoas, pela união, amizade, pelas viagens (com direito a lua cheia, fogueira, viola, chiboquinha,...) e churrascos, pelas horas de estudo (e sono) coletivo, e por muitos dos grandes momentos nesses anos de convivência. Saudades...

Aos funcionários do IPEF e Departamento de Ciências Florestais, principalmente à Marialice, Fátima, Jefferson, Margarete e Zé Martins, por sempre quebrarem os galhos de todo mundo.

Aos estagiários do Laboratório de Ecologia Aplicada Márcia, Fernanda, Marcão e à Alba, pela paciência na ajuda com as análises químicas.

Ao Udemilson e à Regina, por ajudarem sempre nos meus momentos de "caça à estufa".

Às funcionárias da Seção de Pós Graduação da ESALQ pela eterna disponibilidade e paciência.

Ao professor Antonio Natal Gonçalves pela dedicação e amor ao Curso de Pós Graduação em Ciências Florestais, e pelo apoio, sempre bem-vindo e necessário.

Ao programa PET/CAPES, pela bolsa concedida durante o período de realização deste projeto.

Ao IPEF, Instituto de Pesquisas e Estudos Florestais, pelo apoio na reta final, pela oportunidade e pelo aprendizado possibilitado nesse ano de trabalho. 


\section{SUMÁRIO}

LISTA DE FIGURAS

Página

LISTA DE TABELAS

ii

RESUMO

iii

SUMMARY

iv

1. Introdução vi

2. Revisão bibliográfica ..... 1

2.1. A dinâmica das florestas tropicais e a silvigênese. 3

2.2. A Ciclagem de Nutrientes. 3

3. Materiais e métodos 14

3.1. Descrição da área de estudo............................................................................ 25

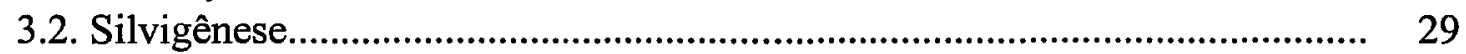

3.3. Ciclagem de nutrientes ................................................................................. 32

3.3.1. Determinação do número e tamanho ideais de coletores ..................... 32

3.3.2 Produção de serapilheira. ..................................................................... 33

3.3.3. Transferência de nutrientes através da serapilheira produzida e eficiência de utilização de nutrientes.......................................................................................... 34

3.3.4. Serapilheira acumulada e taxa de decomposição..................................... 35

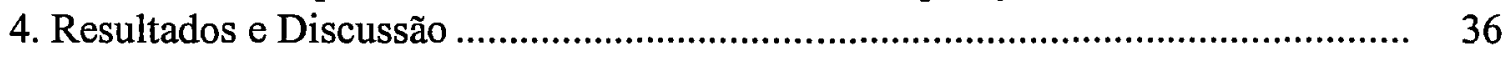

4.1. Silvigênese.................................................................................................. 36

4.2. Ciclagem de nutrientes ............................................................................ 45

4.2.1. Determinação do número e tamanho ideais de coletores ...................... 45

4.2.2 Produção de serapilheira. ...................................................................... 47

4.2.3. Transferência de nutrientes através da serapilheira produzida e eficiência de utilização de nutrientes................................................................................ 55

4.2.4. Serapilheira acumulada e taxa de decomposição................................... 63

5. Considerações Finais............................................................................................. 67

Referências Bibliográficas ................................................................................... $\quad 70$

Anexo - Dados climáticos do período de estudo ....................................................... 80 


\section{LISTA DE FIGURAS}

Página

1. Foto aérea do fragmento estudado e da paisagem circundante; e croqui da área com a localização aproximada das parcelas utilizadas.................................................. 26

2. Chave para eco-unidades em equilíbrio. 1 e 2 = primeiro e segundo níveis do dossel, $\mathrm{A}$ e $\mathrm{B}=$ nível de inversão morfológica alto e baixo (Engel, 1993; baseado em Torquebiau, 1988) .......................................................................................... 30

3. Distribuição de alturas das árvores do presente e do futuro (freqüências absolutas) 39

4. Mosaico florestal e padrão de eco-unidades............................................................ 44

5. Produção total de serapilheira e suas frações ............................................................ 53

6. Total de $\mathrm{N}$ e Ca transferidos pela fração Folhas..................................................... $\quad 62$

7. Total de $\mathrm{P}, \mathrm{K}$ e $\mathrm{Mg}$ transferidos pela fração Folhas

8. Total de N e Ca transferidos pela fração Outros ....................................................... 62

9. Total de $\mathrm{P}, \mathrm{K}$ e $\mathrm{Mg}$ transferidos pela fração Outros

10.Total de $\mathrm{Ne} \mathrm{Ca}$ transferidos pela Serapilheira.................................................... 62

11.Total de $\mathrm{P}, \mathrm{K}$ e $\mathrm{Mg}$ transferidos pela Serapilheira ................................................. 62 


\section{LISTA DE TABELAS}

Página

1. Caracterização do Podzólico Vermelho Amarelo (Solo 01) ................................... 28

2. Caracterização do Podzólico Vermelho Escuro Eutrófico (Solo 02) ..................... 28

3. Caracterização do Podzólico Vermelho Escuro Latossólico (Solo 03)................. 28

4. Caracterização do Gleissolo Eutrófico (Solo 04) .................................................... 28

5. Número e proporção de árvores encontradas nas diferentes categorias ................ 38

6. Distribuição das árvores do presente em diferentes categorias ............................ 38

7. Estrutura e composição de eco-unidades determinadas por mapeamento no campo

8. Porcentagens de área ocupadas pelos diferentes tipos de eco-unidades, no fragmento estudado e em outros trabalhos.

9. Intervalos-padrão sugeridos para as porcentagens das eco-unidades em florestas

10. Valores calculados de $\rho$ (coeficiente de correlação intraclasse), k' (tamanho ótimo de coletores) e $r^{\prime}$ (número ótimo de coletores) para os meses de coleta.

11. Dados de deposição de serapilheira (frações Folhas, Outros e Total) no decorrer do ano de estudo, em kg.ha ${ }^{-1}$

12. Dados de deposição de serapilheira em diferentes formações florestais em t.ha.ano ${ }^{-1}$

13. Concentração dos macronutrientes, nas duas frações analisadas, no decorrer do período de estudo $\left(\mathrm{g} \cdot \mathrm{kg}^{-1}\right)$.

14.Transferência de macroutrientes para o solo através da queda de serapilheira em diferentes formações florestais $\left(\mathrm{kg} \cdot \mathrm{ha}^{-1} \cdot \mathrm{ano}^{-1}\right)$.

15.Relações biomassa / nutriente calculadas para a área de estudo ............................ 59

16.Valores de $\mathrm{K}$ (constante de decomposição) para ecossistemas florestais ............. 64

17. Taxa de decomposição $(\mathrm{K})$, tempo médio de renovação $(1 / \mathrm{K})$ e tempo necessário para a decomposição de 50\% e 95\% da serapilheira. 


\title{
ASPECTOS DA DINÂMICA DE UM FRAGMENTO FLORESTAL EM PIRACICABA-SP: SILVIGÊNESE E CICLAGEM DE NUTRIENTES
}

\author{
Autora: RENATA EVANGELISTA DE OLIVEIRA \\ Orientador: Prof. Dr.FÁBIO POGGIANI
}

\section{RESUMO:}

O presente trabalho aborda a silvigênese e a ciclagem de nutrientes em um fragmento de mata mesófila semidecídua em Piracicaba, São Paulo. O fragmento tem área de 4,9 ha, e é cercado por áreaś agrícolas e reflorestamentos. Procurou-se determinar o quanto distúrbios diversos e a fragmentação afetam essa dinâmica. Estudou-se alguns aspectos do ciclo silvigenético e da arquitetura do fragmento, através de um método que permite reconhecer e levantar a estrutura e composição do mosaico florestal. As árvores dominantes que interceptaram linhas de inventário distantes $5 \mathrm{~m}$ uma da outra, em uma parcela de $50 \times 50 \mathrm{~m}^{2}$, foram mapeadas e categorizadas em árvores do presente, passado e futuro. Estabeleceu-se um mosaico de eco-unidades com base nesse inventário. Essas eco-unidades são classificadas como eco-unidades em reorganização, desenvolvimento, equilíbrio dinâmico e em degradação; que definem o grau de desenvolvimento do mosaico estudado. Das árvores mapeadas, $\underline{63 \%}$ eram do presente, $10 \%$ do passado e $27 \%$ do futuro. A altura máxima encontrada para as árvores dominantes foi de $20 \mathrm{~m}$, sendo que as árvores do presente se distribuíram por todas as classes de altura. Ocorrem altas porcentagens de eco-unidades em reorganização, degradação, e de eco-unidades que representam áreas com distúrbios mais recentes no dossel, ou processos silvigenéticos recentes, e são formadas por árvores baixas. Não há predomínio de eco-unidades que representam a fase madura da floresta. A produção total de serapilheira (estimada mensalmente com 96 coletores de $0,25 \mathrm{~m}^{2}$ agrupados quatro a quatro em conjuntos de $1 \mathrm{~m}^{2}$, de maio de 1995 a abril de 1996), foi de $14.715,97 \mathrm{~kg} \cdot \mathrm{ha}^{-1} \cdot \mathrm{ano}^{-1}$, e a fração folhas contribuiu com $71,58 \%$ da queda de serapilheira. $\mathrm{O}$ número e tamanho ótimos de coletores a serem utilizados nesses estudos foram determinados utilizando-se uma amostragem de duplo estágio, e levando-se em 
conta o coeficiente de correlação intra-classe, entre subcoletores dentro de coletores. $\mathrm{O}$ número ótimo de coletores determinado foi de 60 , com tamanho ideal de $0,25 \mathrm{~m}^{2}$. A transferência total de macronutrientes durante o ano de estudo foi de $703,08 \mathrm{~kg} \cdot \mathrm{ha}^{-1} \mathrm{de}$ Ca, 261,2 kg.ha ${ }^{-1}$ de N, 16,38 kg.ha ${ }^{-1}$ de P, 100,19 kg.ha ${ }^{-1}$ de K e 64,86 de Mg. A eficiência de utilização de nutrientes (relação biomassa/nutriente), para o $\mathrm{N}, \mathrm{P}$ e Ca foram: 55,$24 ; 868,14$ e 19,81 , respectivamente. A serapilheira acumulada foi estimada em 7.745,43 kg.ha ${ }^{-1}$, com uma constante de decomposição $(\mathrm{K})$ de 1,9 , e o tempo necessário para o desaparecimento de $50 \%$ e $95 \%$ da serapilheira foram, respectivamente, 131 e 576 dias. Os resultados mostram uma produção de serapilheira muito alta, provavelmente devido ao grau de perturbação do fragmento estudado, alta infestação por lianas e pela ocorrência de fortes tempestades na área durante esse período. A transferência de macronutrientes também apresenta números altos, devido provavelmente às práticas realizadas nas áreas agrícolas do entorno, como adubações e calagem. Assim, a dinâmica da floresta em anbientes fragmentados e que sofrem perturbações constantes, é afetada em pelo menos dois de seus aspectos básicos: a arquitetura (ciclos silvigenéticos) e ciclagem de nutrientes. 


\title{
ASPECTS OF A FOREST FRAGMENT DYNAMICS IN PIRACICABA- SP: SYLVIGENESIS AND NUTRIENT CYCLING
}

\author{
Author: RENATA EVANGELISTA DE OLIVEIRA \\ Advisor: Prof. Dr. FÁBIO POGGIANI
}

\section{SUMMARY:}

This paper studies the sylvigenesis and nutrient cycling in a semideciduous forest fragment in Piracicaba, São Paulo State. This fragment has a total area of 4,9 ha, and is surrounded by agricultural and planted sites. Through these aspects, this study tried to determinate how disturbance and fragmentation affects this dynamics. Some aspects of sylvigenetic cycles and architecture were studied, using a method which recognizes and inventories the structure and composition of the forest mosaic. Dominant trees intercepting inventory lines far $5 \mathrm{~m}$ from each other, in a plot of $50 \times 50 \mathrm{~m}$, were mapped and categoryzed as present, past and future trees. A mosaic map of different eco-units was established. Those eco-units are classified in reorganizing, aggrading, mature (steady state) and degradimg eco-units, which show the development degree of the fragment. Mapped trees were $63 \%$ present trees, $10 \%$ past trees and $27 \%$ future trees. The highest trees were $20 \mathrm{~m}$, and the present trees were distributed in every class of heights. There were high percents of reorganizing, degrading and eco-units that represent recent disturbing in the forest canopy, or recent sylvigenetic processes, and are formed by short trees. Eco-units that represent forest mature phase are not predominant. The $2 \mathrm{~A}$ and $1 \mathrm{~A}$ eco-units percents are very similar. Total litter production (estimated monthly with 96 traps, each $0,25 \mathrm{~m}^{2}$, in groups of $1 \mathrm{~m}^{2}$ size, from May 1995 to April, 1996), was $14.715,97 \mathrm{~kg} \cdot \mathrm{ha}^{-1} \cdot$ year $^{-1}$, and leaf fraction contributed with $71.58 \%$ of litterfall. The optimum size and number of traps to be used in this kind of study were determined using two-stage sampling and taking in account the intra-class coefficient of 
correlation among sub-traps within traps. The optimum number of traps determined was 60 , with an ideal size of $0,25 \mathrm{~m}^{2}$. Total macronutrients transference during this year was $703,08 \mathrm{~kg} \cdot \mathrm{ha}^{-1}$ of Ca, 261,2 kg.ha- ${ }^{-1}$ of N, 16,38 kg.ha ${ }^{-1}$ of P, 100,19 kg.ha- ${ }^{-1}$ of K and 64,86 of Mg. Nutrient use efficiency (biomass/nutrient relation), for $\mathrm{N}, \mathrm{P}$ and Ca.was: 55,$24 ; 868,14$ and 19,81 , respectively. Litter standing crop was estimated in $7.745,43$ kg.ha ${ }^{-1}$, with a turnover coefficient $(\mathrm{K})$ of 1,9 , and the time required for the disappearance of $50 \%$ and $95 \%$ of the litter were, respectly, 131 and 576 days. The results show a very high litter production, probably because of the degree of disturbance of the fragment, high abundance of lianas and because of storms and strong winds in the area during this year. Macronutrients transference also shows high values, probably because of several practices in the surrounding agricultural areas, like fertilizations and liming. Forest dynamics in fragmented and disturbed sites is affected in at least two of its basic aspects: architecture (sylvigenetic cycles) and nutrient cycling. 
"Vida de planta, gente e animal tem que ser entrelaçada..." Ana Maria Machado

\section{1- INTRODUÇÃO}

Atualmente, 36 milhões de quilômetros quadrados são cobertos por florestas, 0 que corresponde a aproximadamente um quarto da área do globo terrestre.

Estudos diversos têm sido realizados com o intuito de se conhecer melhor a estrutura, composição, fisionomia e dinâmica das diversas formações florestais existentes nas regiões tropicais. Infelizmente, muitas dessas formações estão desaparecendo muito rapidamente, devido à ação predatória do homem.

Via de regra, a intervenção humana em ecossistemas naturais tem um efeito desestabilizador, perturbando seu equilíbrio dinâmico. Dentre as recentes mudanças ocorrendo nas florestas mundiais, destaca-se a fragmentação de remanescentes naturais de florestas em pedaços progressivamente menores, isolados por áreas tomadas pelo desenvolvimento agrícola, industrial e urbano (German Bundestag, 1990; Harris, 1984).

A preservação da diversidade dos habitats florestais significa conservar a capacidade de automanutenção, organização e regulação desses ecossistemas (German Bundestag, 1990).

De modo geral, o processo de fragmentação ocorre quando uma grande extensão de habitat é transformada em numerosas "manchas" menores, com áreas totais pequenas, isoladas de outras por habitats geralmente diferentes dos originais, e levando à extinção de espécies (Costa, 1992).

Entre as conseqüências diretas da fragimentaçã̃o estão a redução da biodiversidade, a redução das relações interespecíficas existentes, o efeito de borda e as alterações microclimáticas, entre outras. 
Um outro efeito a que as florestas estão sujeitas é a secundarização, o que nem sempre está associado à fragmentação "per si".

As chamadas "florestas secundárias", definidas por Brown \& Lugo (1990) como aquelas decorrentes do impacto humano sobre as áreas florestais, constituem em torno de $40 \%$ da área florestal total existente nos trópicos, e suas taxas de formação estão por volta de nove milhões de hectares por ano.

Segundo Giuletti (1992), as regiões do Brasil podem ser associadas a um ou mais biomas; a região Norte à floresta amazônica, a Nordeste às caatingas, a CentroOeste ao pantanal e aos cerrados, e a região Sul aos pampas e florestas de araucária. A Região Sudeste, porém, não está associada a um bioma típico, caracterizando-se pela manutenção de diferentes tipos de vegetação, que se estendem para outras regiões.

Dentre as muitas formações presentes na Região Sudeste, e segundo essa mesma autora, mais para o interior, no rebordo das áreas mais altas, se estabelece a floresta tropical estacional semidecidual - também conhecida por mata mesófila semidecídua- devido principalmente à redução da umidade e à presença de uma estação seca bem definida.

No estado de São Paulo, esta formação aparece apenas em manchas, muitas vezes em íntimo contato com o cerrado, as matas de encosta, ou matas de altitude. A definição precisa desse tipo de floresta é bastante difícil em decorrência da degradação maciça do seu ambiente de ocorrência natural (Leitão Filho, 1987; Catharino, 1989).

O presente trabalho procura abordar alguns aspectos da dinâmica desse tipo de vegetação, em condições muito comuns atualmente - a de um ambiente fragmentado, com altos índices de intervenção antrópica e perturbações recentes, concentrando-se em dois aspectos básicos, a ciclagem de nutrientes minerais e o processo silvigenético (características arquiteturais). 
Os objetivos básicos desse estudo foram:

- Estudar aspectos da silvigênese em um fragmento de floresta, com base na arquitetura arbórea, padrão de mosaicos e distribuição espacial de eco-unidades; e compará-lo com outros fragmentos, fisionomicamente semelhantes e menos degradados, para avaliar o efeito da perturbação antrópica sobre as características silvigenéticas dos ecossistemas florestais.

- Estudar os diversos aspectos da ciclagem de nutrientes, fundamental para a compreensão da manutenção de um ecossistema florestal, com o intuito de observar as possiveis alterações causadas pela ação antrópica.

\section{REVISÃO BIBLIOGRÁFICA}

\section{1- A dinâmica das florestas tropicais e a silvigênese}

A regeneração e estabelecimento das espécies da floresta tropical, bem como o comportamento das mesmas em relação às diferentes condições ambientais são a base para a compreensão da dinâmica florestal. A dinâmica das florestas tropicais, em parte, está relacionada a processos sucessionais, e também à chamada dinâmica de clareiras.

A resposta das plantas à luz, bem como a importância das clareiras no desenvolvimento das florestas tropicais, têm sido abordados em diversos trabalhos, por vários autores, como Budowski (1963, 1965), Brokaw (1985), Denslow (1980, 1987), Hartshorn (1980), Pickett (1983), Martinez-Ramos (1985), Shugart (1984), e Whitmore (1976), entre outros.

A clareira é considerada responsável pela dinâmica sucessional da floresta, permitindo que a floresta madura seja vista como um mosaico de clareiras de diferentes tamanhos, idades e composição de espécies e, portanto, em diferentes estádios de sucessão (Kageyama \& Gandara, 1994). 
O tamanho das clareiras determina o tamanho desses "retalhos", ou seja, determina a coesão do mosaico de diferentes fases estruturais, segundo Whitmore (1976).

Kageyama (1987) afirma que o mosaico da floresta tropical, por conter "pontos" em diferentes estádios sucessionais, é muito importante para entender a diversidade e a estrutura das florestas tropicais e, portanto, a sua conservação.

A luz é um fator ecológico que está ligado aos chamados padrões de mosaicos. Por exemplo, os regimes de radiação numa clareira, sob árvores pioneiras e sob espécies primárias vai ser diferente. Diferenças na quantidade, e na distribuição espectral e espaço-temporal da radiação em diferentes níveis da floresta depende não apenas da quantidade de folhagem, mas também da arquitetura e arranjo das copas. (Torquebiau, 1988).

O conjunto dos processos através dos quais é construída a arquitetura da floresta é denominado de silvigênese. Inclui uma ampla gama de fenômenos, como processos que transformam uma floresta recém-estabelecida -ainda instável arquiteturalmente- numa floresta "madura". (Hallé et al, 1978).

A silvigênese pode ser dividida em fases sucessivas, cada qual num estádio de desenvolvimento, sendo um dinâmico e um homeostático, este último com crescimento mínimo. Os dois processos silvigenéticos estão sempre ocorrendo na floresta: transição entre fases homeostáticas e dinâmicas, e mecanismos de reparo durante as fases de equilíbrio. A silvigênese pode-se iniciar em um local desocupado ou em aberturas na floresta (Hallé et al, 1978).

O "chablis" (Oldeman 1978, 1983, 1990) é uma clareira formada pela queda de uma única árvore. O termo "chablis" não se refere apenas à abertura no dossel, mas inclui o processo de queda, a árvore caída, a abertura formada (clareira) e os destroços resultantes no piso da floresta. Hallé et al (1978) sugerem que em torno de 3 a $5 \%$ da área em florestas naturais são submetidas a distúrbios na forma de "chablis". 
Segundo Oldeman (1978), nas diferentes partes de um "chablis", prevalecem níveis diferentes de energia. Onde a copa caiu, há um epicentro (onde estão os galhos maiores) e uma periferia, e onde a copa estava anteriormente, está a clareira. A silvigênese ocorre em diferentes modalidades nesses três locais.

Como se pode observar, o dossel florestal, além de altamente heterogêneo, é também altamente dinâmico, e sofre mudanças continuamente no tempo e no espaço.

O dossel de uma floresta muda à medida que as árvores crescem e morrem e outras a substituem. Segundo Whitmore (1976), o processo de desenvolvimento da floresta ocorre em três fases: a fase de clareira, a fase de construção e a fase madura. A floresta passa da fase de clareira, contendo mudas e árvores jovens, à fase de construção, que é um trecho de floresta jovem e amadurece através de um crescimento contínuo de suas árvores constituintes, passando então à chamada fase madura.

Segundo Oldeman (1978), a floresta tropical é um mosaico de "facetas coexistentes", cada qual representando um ponto cronológico na silvigênese positiva.

O autor afirma que a floresta "aniquila" partes de si mesma (silvigênese negativa) e desenvolve novas partes (silvigênese positiva). Os "agentes de destruição", ou seja, os causadores da silvigênese negativa, seriam as árvores que caem, formando as clareiras.

Entre unidades em diferentes estádios existem "limites" verticais que nos permitem delimitar a superficie dos componentes do mosaico, que são as eco-unidades. Os limites horizontais dessas unidades diferem de acordo com seu estádio de desenvolvimento, tamanho e forma. Entẵo, o ecossistema florestal apresenta limites que permitem dividir a floresta em dois níveis hierárquicos: as eco-unidades e os mosaicos (Oldeman, 1986).

Uma eco-unidade é uma unidade de vegetação que começou a crescer numa determinada superfície num mesmo momento no tempo. A arquitetura, ecofisiologia e 
composição de espécies dessa vegetação são comandadas por um mesmo conjunto de espécies até o final do desenvolvimento da mesma (Oldeman, 1983, 1990).

As eco-unidades de uma floresta podem ser divididas de acordo com seu tamanho (Oldeman, 1989). Segundo este mesmo autor (1983), a superfície das ecounidades é determinada pela origem. A menor eco-unidade possível é o "chablis". O tamanho do "chablis" depende do tamanho da árvore caída (Oldeman, 1978).

Segundo Engel (1993), são duas as características fundamentais que definem uma eco-unidade; o tamanho e a idade a partir do momento de formação. Esse momento é determinado pela freqüência de ocorrência dos fatores de origem (Oldeman, 1983).

O tamanho original da eco-unidade irá determinar seu comportamento subseqüente, o tipo de processo dominante e as estratégias de ciclo de vida das espécies que a compõem (Engel, 1993). Eco-unidades grandes geralmente são formadas por árvores pioneiras, mas são menos freqüentes que as pequenas, que são formadas por espécies tolerantes de crescimento lento (Oldeman, 1989).

Quanto à estratégia de regeneração e ciclo de vida das espécies dominantes, as eco-unidades podem ser classificadas em diferentes tipos (Oldeman, 1983): as ecounidades pioneiras possuem ciclo de vida curto (até dez anos), poucas espécies, arquitetura monótona e tamanho grande. Eco unidades pioneiras tardias possuem ciclo de vida de até cem anos e características intermediárias entre os outros dois tipos. Ecounidades longevas (homeostáticas) são dominadas por espécies arbóreas de ciclo de vida longo (mais de cem anos), possuem muitas espécies, com arquitetura variada, e seu tamanho é pequeno. Este último tipo é o predominante em uma floresta primária. Os três tipos passam pelas mesmas fases de desenvolvimento arquitetural (inovação, desenvolvimento, maturidade e degradação), conforme será discutido mais adiante.

O crescimento de uma eco-unidade é considerado como uma seqüência de fases de desenvolvimento arquitetural. A diagnose da fase arquitetural de um sistema num determinado nível é feita pela diagnose do estado arquitetural dos componentes do 
nível imediatamente inferior, ou seja, a fase de crescimento de uma eco-unidade é vista em termos do desenvolvimento da arquitetura das árvores que a constituem. A arquitetura geral no nível da eco-unidade depende de sua origem e da arquitetura de suas árvores. A arquitetura da floresta diagnostica o padrão de eco-unidades no mosaico (Oldeman, 1983, 1989).

O espaço ocupado por uma árvore durante sua vida, delimitado por sua arquitetura, é caracterizado por certos gradientes ecológicos, sobretudo verticais (Engel, 1993).

Esses gradientes são melhores explicados pelos conceitos de pontos e superfície de inversão ecológica. O ponto de inserção do ramo vivo mais baixo na árvore é chamado ponto de inversão morfológica, e o ponto à metade da altura total é o ponto de inversão ecológica. Um ramo vivo abaixo do meio indica uma morfogênese positiva numa situação ecológica de aumento de oferta de energia. Quando esse ponto fica na segunda metade do tronco, predomina uma morfogênese negativa, indicando diminuição no nível energético do ambiente (Oldeman, 1978).

A união dos pontos de inversão de todas as árvores dominantes formam a superfície de inversão morfológica da floresta (Torquebiau, 1986). Engel (1993) citando outros autores, afirma que, em florestas maduras, a superfície de inversão ecológica fica estabilizada por muito tempo aproximadamente à metade da altura máxima do dossel. A superfície de inversão ecológica é um plano teórico que corta o volume vertical da floresta e corresponde à união dos pontos onde o gradiente das condições ecológicas ao longo do perfil vertical da floresta sofrem mudanças mais drásticas.

As árvores, através de sua arquitetura, dividem o volume ocupado por sua ecounidade em volumes pequenos, cada qual com suas condições microclimáticas e de nutrientes. Quanto mais variada a arquitetura das árvores constituintes de uma ecounidade, mais diversos os nichos, e mais ricas a fauna e a flora. 
A arquitetura das eco-unidades determina a disponibilidade dos nichos para outros organismos; já que a arquitetura muda com o crescimento da floresta, então diferentes nichos aparecem e desaparecem (Oldeman, 1983).

A diversidade de eco-unidades e de gradientes ambientais entre elas codeterminam os nichos, e conseqüentemente a diversidade potencial de espécies. Parece haver uma relação inversa entre o tamanho das eco-unidades e a diversidade de espécies, ou seja, a diversidade diminui à medida que o tamanho da eco-unidade aumenta (Oldeman, 1983).

Como já foi citado, a diagnose da arquitetura das eco-unidades da floresta está baseada na arquitetura de suas árvores constituintes. Oldeman $(1978,1979,1987,1989)$ define, segundo as características arquiteturais, três diferentes categorias de árvores: árvores do presente, passado e futuro.

Árvores potenciais ou do futuro são aquelas que ainda têm potencial para crescimento em altura, expansão da copa ou ambos, ou que ainda não reiteraram.

As árvores do presente já atingiram a expansão máxima e podem ser reconhecidas por uma reiteração prolífica de vários tipos. Essas árvores têm capacidade de se manter na área por muito tempo, devido à sua habilidade de repor partes perdidas. Arquiteturalmente, dominam a floresta.

As árvores do passado perderam a capacidade de reiteração, estão danificadas, ou estão morrendo ou mortas.

Os termos "conjunto do presente, do passado e do futuro" são usados quando essas fases participam como grupos na silvigênese. $O$ conjunto do presente é dividido em conjuntos estruturais a diferentes níveis de altura (Oldeman, 1978), que formam os estratos.

Os processos de crescimento podem ser diagnosticados e explicados pelo estado das árvores componentes. Se há principalmente árvores potenciais, elas 
competem e crescem rapidamente em direção ao dossel. Quando algumas árvores atingiram o estado de presente, estas dominam a arquitetura do sistema todo.. Quando estas decaem e se tornam árvores do passado, o sistema todo vai ser substituído por um ou mais sistemas. A seqüência de desenvolvimento de uma eco-unidade é passar através de uma fase de inovação, uma fase de desenvolvimento, uma fase biostática ou em equilíbrio dinâmico e uma fase de degradação. A substituição das árvores automaticamente leva à morte da eco-unidade em questão,e sua conseqüente substituição por uma ou mais eco-unidades. Assim, o desenvolvimento das eco-unidades é tratado como um "subprocesso da sucessão" (Oldeman, 1989,1990).

Oldeman (1990) dá uma descrição detalhada de como ocorre o desenvolvimento de cada uma dessas fases, como citado a seguir:

O desenvolvimento de toda eco-unidade começa com uma fase de inovação. A eco-unidade nessa fase não tem arquitetura durável. Essa fase é pouco estruturada e muito dinâmica; e contém espécies de plantas e animais de vida curta, as espécies inovadoras. Essas espécies ocorrem em cada fase de inovação de todos os tipos de ecounidades.

Atuando como uma fonte de espécies, o mosaico florestal circundante também regula os processos dentro da eco-unidade jovem. Nessa fase há uma sequência rápida de espécies animais e vegetais e interações entre elas, antes desta seqüência tornar-se mais lenta para uma arquitetura mais permanente.

Depois da fase de inovação, vem a fase de desenvolvimento. Seu início é bem definido no tempo, porque começa assim que o dossel florestal se fecha.

Arquiteturalmente, começa com o primeiro passo na estruturação da ecounidade. $\mathrm{O}$ fechamento do dossel significa que uma camada-limite mais alta cobre agora a eco-unidade, agindo como um filtro. Essa função é realizada pelas árvores. Se o desenvolvimento de camadas de lianas for muito forte, uma cobertura de lianas pode estar fazendo esse papel no fechamento do dossel. 
A fase de desenvolvimento dura muito mais que a de inovação, geralmente dez anos ou mais. Uma vez fechado, o dossel é muito denso e o número de árvores é alto. Durante essa fase, muitas árvores morrem ou "ficam pra trás"no desenvolvimento. Muitos componentes da fase de inovação são eliminados na fase de desenvolvimento, porque seus nichos desaparecem, uma vez que a eco-unidade se torna auto-reguladora devido a seu compartimento arbóreo. Em resumo, essa fase é a primeira a mostrar um padrão arquitetural.

O resultado da fase de desenvolvimento é a fase biostática. Nessa fase, as ecounidades são mais claramente organizadas. Sua arquitetura é persistente. As árvores que determinam esta arquitetura são as árvores do presente, porque elas não têm mais potencial para expandir a copa. Essas árvores podem ser consideradas como o conjunto do presente, e este conjunto é subdividido em outros conjuntos estruturais a diferentes alturas. As árvores do futuro ainda sobreviventes, que tem um potencial para expansão futura, subsistem como árvores suprimidas.

Os componentes arbóreos têm uma função de transformação na arquitetura das eco-unidades. Segundo Oldeman (1983), a estratificação em fases de equilíbrio é definida exclusivamente por árvores do presente, sendo que as outras têm sua arquitetura também definida por elas.

Quando as árvores estão no período inicial de desenvolvimento, conservam potencial para expansão de copa. Durante esse período, expressam este potencial numa fase de desenvolvimento, ou este potencial não é usado enquanto as árvores ficam suprimidas numa fase biostática.

As árvores do presente têm por destino, mais cedo ou mais tarde, se tornarem árvores do passado (senescem e morrem). Mas antes disso, se mantêm por um longo tempo substituindo partes perdidas através de reiteração. A fase biostática contém árvores em todos os três estados (passado, presente e futuro), portanto serve como exemplo para explicar mais facilmente esses estados. 
Quando a biostase é quebrada, a eco-unidade entra numa fase de degradação. A degradação prepara o evento zero, (evento criador da eco-unidade), porque limpa o espaço ocupado por uma eco-unidade para reocupação por outras.

A degradação é um processo lento iniciado pela senescência das árvores. Mas pode ser muito rápida quando causada por acidentes como fogo, ventos, inundações, erosão, etc. Pode também ser causada bioticamente, quando algum componente da floresta monopoliza ou drena a capacidade de produção da floresta à custa das árvores (por exemplo pragas e insetos).

Durante essa fase, as árvores do passado, que organizaram a arquitetura da floresta biostática, decaem e param de construir ambientes necessários aos componentes não arbóreos. $O$ evento de separação entre as fases de degradação e inovação é a morte da eco-unidade em questão, que pode arbitrariamente ser fixada no momento da morte das árvores do presente.

Segundo Oldeman (1983), além das eco-unidades, existem outros níveis de integração através dos quais a arquitetura dinâmica das florestas tropicais podem ser analisadas: a crono-unidade ou mosaico de desenvolvimento e a unidade silvática ou mosaico sucessional, também denominado mosaico silvático.

Uma crono-unidade é a superficie mínima que contém todas as fases de uma eco-unidade específica (fases em reorganização, em equilibrio dinâmico e em degradação). Uma unidade silvática inclui crono-unidades de todo tipo de eco-unidade num determinado local. A crono-unidade pode apresentar três estados arquiteturais, importantes para a determinação do nível de organização seguinte, a unidade silvática (Engel,1993). Uma crono-unidade é diferente de outra se suas eco-unidades constituintes são diferentes. Quando em uma floresta, algum tipo de eco-unidade está presente predominantemente em fases iniciais, ou em desenvolvimento, a crono-unidade é " $\mathrm{em}$ aparecimento". Se esta apresenta proporções aproximadamente iguais de eco-unidades em desenvolvimento, equilíbrio e degradação, a crono-unidade é "dominante". Uma 
crono-unidade com principalmente eco-unidades em degradação está "em desaparecimento".

As eco-unidades não são ilhas isoladas, mas subsistemas que interagem no mosaico silvático. Por mais complexos que sejam os impactos que criam uma nova ecounidade, o resultado é um mosaico com uma dinâmica previsivel (Oldeman, 1989).

Os cinco estádios silvigenéticos do desenvolvimento de um mosaico silvático são: estádio de instalação, estádio de pré-equilíbrio, estádio de equilíbrio, estádio de eliminação e estádio de colapso (Oldeman, 1990). O autor descreve o comportamento do mosaico silvático através dessas cinco fases, como descrito a seguir:

Durante a fase inicial do estádio de instalação, todas as eco-unidades estão na fase de inovação. Um mosaico nesse estádio só tem crono-unidades em aparecimento. $\mathrm{O}$ pré-equilíbrio, arquiteturalmente, começa com o fechamento do dossel do mosaico. $\mathrm{O}$ estádio de equilíbrio de um mosaico silvático é caracterizado por uma composição de eco-unidades dinamicamente constante. Cada eco-unidade que desaparece é substituída em algum lugar no mosaico por outra do mesmo tipo. A diversidade nas eco-unidades é mais alta nesse estádio, e com ela, a diversidade de espécies. O sistema de interação entre eco-unidades, implementado em grande parte por animais, é mais altamente organizado nesse estádio. Sendo o mais complexo estádio de desenvolvimento de todos, ele é mais difícil de manejar.

Quando um estádio de equilíbrio entra em stress, o resultado é um estádio de eliminação do mosaico silvático. Nesse estádio ocorre a perda de certos tipos de ecounidades, particularmente as menores e mais raras, que dependem de interações precisas com as vizinhas para sobreviver. A arquitetura de um mosaico silvático no estádio de eliminação pode ser reconhecida por proporções cada vez maiores de eco-unidades pioneiras de tamanho grande (com espécies lenhosas), e por eco-unidades herbáceas. 
O estádio de colapso segue os estádios de eliminação. $O$ colapso é um estádio que pode levar o mosaico de volta a um novo estádio de instalação muito diferente do original.

Do ponto de vista silvigenético, em uma área de floresta, para que sejam garantidos seus processos de crescimento e renovação, e mantida a estabilidade desejada, deve-se ter uma superfície mínima que contenha todos os tipos e estádios de ecounidades e de modo que a taxa de renovação dessas eco-unidades seja mantida nos níveis próximos aos normais (Engel, 1993).

Essa autora afirma que, ao se considerar os efeitos da fragmentação sobre as unidades silváticas e estudar o problema através de uma análise arquitetural, podemos realizar um diagnóstico da situação atual dos fragmentos e possíveis previsões da situação futura, sem necessidade de estudos a longo prazo como requerem os estudos demográficos.

Deve-se lembrar, entretanto, que é importante levantar o histórico de perturbação da área a ser estudada, a fim de se realizar um diagnóstico mais preciso, e de se compreender melhor o processo silvigenético.

A análise arquitetural de mosaicos permite, por exemplo, verificar se o número de eco-unidades em formação ("chablis") é maior que o número de eco-unidades em degradação, ou se o número de eco-unidades em degradação pode ser reposto pelas ecounidades em desenvolvimento e assim por diante. A análise silvigenética, então, permite um diagnóstico seguro do estádio de desenvolvimento da floresta em termos arquiteturais e sucessionais. De acordo com esse diagnóstico pode-se até prever o "comportamento" da dinâmica de uma determinada floresta, e também determinar quais as práticas de manejo mais adequadas num determinado ecossistema florestal, para garantir sua auto-sustentabilidade e perpetuação (Engel, 1993). 


\section{2- A Ciclagem de Nutrientes}

Os elementos químicos tendem a circular na biosfera em vias características, do ambiente aos organismos e destes novamente ao ambiente. O movimento desses elementos e compostos inorgânicos que são essenciais à vida pode ser adequadamente denominado ciclagem de nutrientes (Odum, 1983).

O conhecimento dessa ciclagem entre os diversos compartimentos dos ecossistemas e destes para o ambiente circundante pode contribuir para a elucidação das interações entre os seres vivos e o meio, já que são fundamentais para a manutenção da integridade dos diversos sistemas ecológicos (Delitti, 1982).

Estudos demonstram que interações biológicas podem estar empiricamente ligadas ao maior fluxo de nutrientes numa floresta natural, com possíveis benefícios aos "participantes". Cada organismo, com suas adaptações específicas deve desempenhar um papel importante no controle dos estoques de nutrientes, com relação ao tamanho desses estoques e às taxas de transferência entre eles (Snedaker, 1980). Os mecanismos de absorção, estoque, transferência e perda de elementos na floresta são explicados pelo comportamento coletivo dos organismos vivos que compõem a comunidade florestal (Golley, 1983).

Segundo Odum (1983), dos mais de noventa elementos conhecidos na natureza, sabe-se que trinta a quarenta são necessários aos organismos vivos, sendo que alguns são necessários em grandes quantidades, outros em quantidades pequenas ou até mínimas. Seja qual for essa necessidade, os elementos essenciais exibem ciclos bem definidos.

Por exemplo, Arcova (1993) afirma que os ciclos dos nutrientes $\mathrm{Ca}, \mathrm{Ng}$ e $\mathrm{K}$ diferem muito de $\mathrm{N}, \mathrm{P}$ e $\mathrm{S}$ em vários aspectos. Processos inorgânicos como o intemperismo, troca catiônica e lixiviação do solo são freqüentemente mais importantes para os três primeiros, sendo a imobilização heterotrófica e oxidação de menor 
importância. O Ca, $\mathrm{Mg}$ e $\mathrm{K}$ entram nos ecossistemas florestais por deposição de materiais. Em termos médios, o $\mathrm{K}$ e o Ca são os elementos com maiores fluxos na água que passa pelo dossel, tanto na precipitação interna quanto para o escorrimento superficial.

O conjunto da circulação dos elementos minerais através do ecossistema, consta de várias fases: absorção, assimilação e armazenamento na biomassa, volta ao solo com a manta orgânica ou pelas chuvas, acumulação e decomposição na superficie do solo e mineralização, ficando assim disponível no meio edáfico para a vegetação. Uma maior ou menor eficiência no uso de nutrientes positivamente depende da ciclagem de nutrientes, o que contribui com o aumento ou diminuição da fertilidade do solo (Haag, 1985; Breemen et al, 1995).

Poggiani (1992), afirma que o fluxo de nutrientes na floresta não segue caminhos rígidos, mas varia de acordo com a estrutura e o funcionamento dos ecossistemas característicos das diferentes zonas de vida da Terra; ou seja, em cada ecossistema os nutrientes têm sua forma característica de ciclagem. Os nutrientes são gradualmente acumulados no sistema vegetação-solo e tendem a ser distribuídos entre os vários compartimentos de maneiras consideradas características para os diferentes biomas (Packham et al, 1992).

Segundo Switzer \& Nelson (1972), as fontes de nutrientes nos sistemas são: nutrientes transferidos dentro da biomassa, derivados da decomposição de materiais orgânicos; nutrientes na precipitação; adição de nutrientes à precipitação devido à lavagem e escorrimento pelo dossel, e derivados de fontes minerais. Esses autores sugerem o reconhecimento dos seguintes ciclos dentro dos sistemas: a) geoquímicos, que abrangem relações de importação e exportação, b) ciclos biogeoquímicos, que abrangem as relações solo-planta, e c) ciclos bioquímicos, que abrangem relações de transferência internas ou translocação de nutrientes dentro das árvores. 
Um dos aspectos mais importantes na ciclagem de nutrientes é a produção e decomposição da serapilheira e as transferências de elementos liberados através destes processos (Delitti, 1982). O estudo do compartimento da serapilheira justifica-se pelo importante papel que desempenha na ciclagem de nutrientes da biomassa para o solo (Meguro et al, 1979a). A deposição deste material orgânico é uma das principais transferências que ocorrem no ecossistema florestal, e sua periodicidade varia de espécie para espécie, sendo que os fatores climáticos influenciam significativamente nesse fenômeno (Schumacher, 1992).

A matéria orgânica sobre a superficie do solo é a principal reserva para o $\mathrm{N}$ e o $\mathrm{S}$ do solo, e também um importante reservatório para $\mathrm{P}, \mathrm{Ca}, \mathrm{K}$ e $\mathrm{Mg}$ (Jordan, 1985; Pritchett, 1987).

Proctor (1983) afirma que o litter ou serapilheira reveste-se de grande importância em virtude de constituir um índice de produção da floresta; prover informações sobre a taxa de decomposição do material decíduo da árvore, e determinar um importante caminho no ciclo de nutrientes minerais, indicando sua eficiência.

Muitos fatores podem afetar os padrões de ciclagem de nutrientes (deposição de material e circulação de elementos minerais) nos ecossistemas. Jordan (1985) cita fatores ambientais, como a temperatura e interações entre temperatura e umidade, e fatores bióticos, como a produtividade primária, herbivoria, decomposição, balanço entre produtividade e decomposição; além da influência desses fatores bióticos no intemperismo e na lixiviação.

Vitousek \& Sanford (1986) citam ainda o clima, a composição de espécies, o estádio sucessional da vegetação e a fertilidade do solo como fatores que causam variações na ciclagem de nutrientes em ecossistemas florestais.

A deposição do litter ou serapilheira pode sofrer influências diversas, como da latitude, clima, altitude, exposição à insolação solar, caráter decíduo ou sempre verde das 
espécies, da fertilidade do solo (Bray \& Gorham, 1964), dos teores de alguns nutrientes no solo, como do nitrogênio (Vitousek, 1982), da riqueza de espécies vegetais (Burnham, 1994), e de características climáticas sazonais (Wright \& Cornejo, 1990; Cornejo et al, 1994; Wieder \& Wright, 1995), entre outros.

Espécies diferentes apresentam capacidades diferentes de absorver, acumular e ciclar diferentes quantidades dos diversos elementos, de acordo com suas características fisiológicas distintas. Segundo Montagnini \& Sancho (1994), as espécies diferem em suas taxas de acúmulo de nutrientes nos tecidos. Para uma mesma espécie, não são mantidos os mesmos padrões para todos os elementos.

Szott et al (1994) cita diferenças no acúmulo de biomassa e serapilheira entre as diferentes espécies num mesmo plantio, entre plantios diferentes e entre esses e uma floresta natural secundária. Lisanework et al (1994) também cita diferenças na queda de serapilheira entre espécies plantadas e a floresta natural na Etiópia, sendo que a deposição maior ocorreu na floresta natural.

Segundo Burnham (1994), também a contribuição das diferentes categorias de formas de vida na floresta reflete no acúmulo de serapilheira sob dosséis florestais tropicais.

O padrão na queda de serapilheira pode ser distintamente sazonal ou mais ou menos contínuo. Algumas espécies em florestas tropicais são distintamente decíduas, não necessariamente ligadas a nenhum tipo de ciclo anual. $\mathrm{O}$ padrão e o momento da reposição foliar é extremamente variável, e dependente de fatores internos e externos. (Bray \& Gorham, 1964). Segundo Delitti (1982) a produção de folhedo tem um padrão anual diversificado, sendo comuns os ecossistemas em que ocorre produção de material durante todo o ano, com períodos de maior ou menor intensidade, relacionados a fatores ambientais e genéticos. 
Os teores de nutrientes e sua circulação no ecossistema podem ser influenciados, por sua vez, pelo tipo e idade da cobertura florestal e pelas condições de clima e solo da comunidade (Pritchett, 1987). Ribeiro (1983) cita que a concentração de um determinado nutriente na planta como um todo ou em parte dela, é função não só do solo, como do clima, da espécie, da hora do dia, da estação do ano, idade da árvore e da folha, posição da copa, balanço de nutrientes, efeito de doenças, entre outros.

Flutuações nas condições ambientais podem induzir pulsos de mineralização de nutrientes e flutuações nas populaçõpes microbianas que afetam o destino dos nutrientes em ecossistemas florestais (Lodge et al, 1994)

Segundo Bonilla \& Ròda (1990), distúrbios ocorrendo em escalas de tempo e espaço variados, e com diferentes graus de intensidade também podem afetar os padrões de ciclagem de nutrientes. Deve ocorrer aumento nas perdas de nutrientes em ecossistemas perturbados.

Engel (1993) cita a importância das lianas na ciclagem de nutrientes, afirmando que a colaboração dessas plantas na ciclagem e conservação dos nutrientes pode ser muito maior do que se pensa. Durante a sucessão secundária, as lianas ajudam a reter os nutrientes na biomassa.

A autora cita o trabalho de Vinha et al $^{1}$, que observaram que após derrubada e queima da mata, quantidades significativas de nutrientes estavam retidas na vegetação pioneira e que os cipós representavam uma grande proporção da biomassa.

Florestas secundárias acumulam nutrientes rapidamente com o tempo, embora as proporções de nutrientes na vegetação, serapilheira e solo variem com o elemento. Uma alta fração do estoque total de nutrientes é obtido cedo no desenvolvimento da floresta, e à medida que esta se desenvolve, as concentrações de nutrientes se diluem

\footnotetext{
1 VINHA,S.G; CADIMA, A.; SANTOS, O.M. A fase pioneira de uma sucessão vegetal no sul da Bahia: estrutura e composição química da vegetação Theobroma, Itabuna, v.13, n.1, p.27-34, 1983.
} 
pelo aumento da biomassa não funcional com baixas concentrações de nutrientes (Brown \& Lugo, 1990). As sucessões em florestas secundárias são supridas com o excesso de nutrientes liberados e tornados disponíveis, usualmente pelo mesmo agente que iniciou a sucessão ou recobrimento da floresta (Snedaker, 1980).

Vitousek \& Reiners (1975) afirmam que são esperadas variações na biomassa produzida e na sua composição elementar através da sucessão.

Segundo Snedaker (1980), a riqueza de espécies aumenta com a sucessão, o que resulta num aumento das interações potenciais entre as espécies. Essas interações e padrões de vida associados envolvem o "movimento de massa" e de seus elementos químicos constituintes.

Estudos realizados por Tilman (1990), sobre a dinâmica sucessional numa vegetação rasteira em Minnesota (EUA), mostraram que os fatores limitantes ao desenvolvimento foram principalmente o nitrogênio do solo ( a competição pelo $\mathrm{N}$ ) e as perturbações. Outros nutrientes $(\mathrm{P}, \mathrm{K}, \mathrm{Ca}, \mathrm{Mg}, \mathrm{S}, \ldots)$, a herbivoria e a luz também atuaram como fatores limitantes, com menor importância.

Existe um consenso de que, em florestas tropicais, os nutrientes minerais ficam concentrados na biomassa, e não no solo, como ocorre nas florestas temperadas

Jordan (1985) afirma haverem mais locais em florestas tropicais com altos estoque de $\mathrm{Ca}$ e $\mathrm{K}$ na biomassa, e mais $\mathrm{N}$ no solo.

Golley et al (1975) afirma que essas florestas têm uma grande massa de elementos químicos presos na madeira de troncos, ramos e raízes que se move de um modo relativamente lento através do sistema. Por outro lado, uma massa menor associada às partes verdes e à serapilheira é reciclada rapidamente entre o solo e as plantas. Uma alta produtividade anual que ocorre geralmente nas florestas tropicais 
significam também altas taxas de retorno de nutrientes ao solo pela queda de folhas (Jordan, 1985).

Um ecossistema está apto a se auto-sustentar em solos relativamente pobres, desde que os nutrientes circulem num sistema bem adaptado para prevenir suas perdas. A conservação de nutrientes essenciais e sua eficiência de utilização no crescimento é requerida para sustentar a produção florestal, especialmente quando muitas florestas estão localizadas em sítios pobres em nutrientes.(Vogt et al, 1986; German Bundestag, 1990).

Enquanto todas as florestas apresentam mecanismos para conservação de nutrientes, especula-se que estes sejam mais desenvolvidos em florestas tropicais (Golley, 1983). Segundo Jordan (1985) isso ocorre porque solos pobres são comuns em regiões tropicais, e por isso esses mecanismos são comumente relacionados com esses ecossistemas.

Florestas pobres em nutrientes são mais comuns nos trópicos que em regiões temperadas. Nessas áreas os nutrientes parecem ser limitantes ao crescimento das plantas, uma vez que florestas naturais são destruídas para a instalação de culturas agrícolas ou florestas homogêneas implantadas. A produtividade e a ciclagem de nutrientes em florestas ricas ou pobres em nutrientes não diferem muito, enquanto esses ecossistemas não sofrem distúrbios. Mas, quando as florestas são retiradas para agricultura, os sistemas pobres perdem rapidamente seu potencial produtivo, enquanto que os ricos não. O ecossistema pobre é capaz de manter sua produtividade em condições não perturbadas através de mecanismos de conservação de nutrientes, dos quais os mais importantes estão associados ao húmus e à camada de raízes no topo do solo mineral (distribuição superficial das raízes). Outros mecanismos são biomassa radicular grande, raízes aéreas e micorrizas. Quando a floresta é submetida a distúrbios naturais ou antrópicos, esses mecanismos (alguns ou todos) podem ser destruídos (Jordan et al, 1981; Jordan, 1985) 
Veneklaas (1991) afirma que os nutrientes perdidos nas folhas que caem representam perdas consideradas pequenas quando a disponibilidade de nutrientes no solo é altạ e sua absorção fácil, mas em ambientes com baixa disponibilidade, essas perdas requerem adaptações especiais. Potter et al (1987) citam a reabsorção dos nutrientes foliares numa floresta sucessional, durante o outono (época de maior perda de folhas). Esse processo conserva os nutrientes por reduzir perdas na lixiviação e queda de serapilheira, fechando o ciclo de nutrientes. Trata-se de um mecanismo de conservação de nutrientes para espécies em solos pobres.

Olson (1963) já afirmava que "baixas porcentagens de carbono em florestas tropicais altamente produtivas contrastam com altos níveis de carbono e acúmulo de energia nas relativamente improdutivas florestas temperadas. Uma principal razão para isso envolve as taxas em que a matéria orgânica morta é quebrada ou incorporada ao solo mineral por organismos".

Assim, outro aspecto bastante estudado na ciclagem de nutrientes é a decomposição da serapilheira.

A decomposição é o processo mais importante de transferência de nutrientes da vegetação ao solo (Reis, 1984). Fatores como as taxas de decomposição de serapilheira e mineralização de nutrientes contribuem para uma maior ou menor eficiência na utilização de nutrientes nos ecossistemas (Breemen et al, 1995).

A decomposição se refere aos processos químicos e físicos envolvidos na redução de matéria orgânica morta na vegetação e nos animais para seus elementos químicos constituintes (Golley, 1983). Por uma série de processos físicos, químicos e biológicos, a serapilheira é decomposta e os nutrientes nela incorporados são liberados, podendo novamente ser absorvidos pelos produtores primários (Delittii, 1982).

Wieder \& Lang (1982) descrevem a dinâmica da decomposição em dois passos: no primeiro ocorre a utilização rápida pelos decompositores de componentes 
solúveis e compostos facilmente degradados, como açúcares e proteínas. O segundo passo é descrito como a perda de materiais mais recalcitrantes, como a celulose, taninos e ligninas.

Várias intervenções, agindo simultaneamente e/ou em seqüência sobre a necromassa, pode realizar mudanças químicas e estruturais. Componentes solúveis são lixiviados pela água da chuva, enquanto que a degradação de substratos químicos é realizada principalmente por atividades catabólicas dos decompositores, especialmente fungos e bactérias, assim como pela ação de enzimas autolíticas dos tecidos mortos e pelo fogo. À medida que uma unidade individual de necromassa se deteriora progressivamente, há uma mudança na disponibilidade de recursos particulares, como energia e nutrientes. A maioria das mudanças químicas na composição, especialmente em seus componentes estruturais como lignina e celulose, são realizadas por enzimas microbianas (Packham et al, 1992).

As taxas de decomposição podem ser afetadas pela umidade, temperatura, evapotranspiração, composição química do material, características morfológicas e anatômicas, composição e atividade dos organismos detritívoros e saprófagos do solo, sazonalidade nos teores de umidade, e precipitação (Thaiutsa \& Granger, 1979; Swift et al, 1979; Fassbender \& Grimm, 1981; Cornejo et al, 1994 e Wieder \& Wright, 1995). Zhang et al (1995) descreve a influência de diferentes tamanhos de clareira nas taxas de decomposição. Clareiras grandes reduzem significantemente a atividade microbiana e as taxas de decomposição, por alterarem as condições ambientais.

A serapilheira de plantas diferentes não apresentam a mesma velocidade de decomposição, devido às diferenças na estrutura e composição das folhas e de outras partes das plantas (Reis, 1984). A taxa de decomposição desse material é maior nos trópicos (Jordan, 1985), devido à influência dos fatores climáticos. 
Em geral, as florestas tropicais produzem em torno de 5 t.ano ${ }^{-1}$ como input ao sistema decompositor. A conversão desssa matéria orgânica para húmus ocorre a uma taxa de 30 a $50 \%$ ao ano. Folhas se decompõem mais rapidamente que galhos, ramos e troncos. A decomposição das folhas pode ocorrer de três a seis meses sob condições de alta temperatura e precipitação. Os padrões temporais nas taxas anuais e diárias de queda de serapilheira e decomposição da matéria orgânica refletem a variação ambiental da região (Golley, 1983).

Segundo Poggiani (1992) a diversidade biológica favorece a cadeia alimentar ampliando a variedade de organismos e microorganismos que colaboram na decomposição. Os fatores ambientais são muito importantes na determinação da taxa de decomposição.

Os vários organismos ativos na decomposição incluem bactérias, fungos, protozoários, nematóides, macro e microartrópodos, etc. As bactérias e fungos podem ser significantes na reciclagem de nutrientes da serapilheira para as raízes. Em florestas tropicais, a decomposição é mediada principalmente por bactérias e fungos, sendo os fungos especialmente importantes (Golley, 1983).

Spurr \& Barnes (1973) afirmam que em condições ótimas para atividade biológica (solo suficientemente aquecido, úmido e arejado durante grande parte do ano), a decomposição deverá ocorrer satisfatoriamente, sem acúmulo de matéria orgânica. Essa atividade pode ser inibida por frio, acidez, condições insatisfatórias com relação à umidade e pouco arejamento, fazendo com que ocorra um maior acúmulo de serapilheira.

Acredita-se que a microflora é responsável por mais ou menos $80 \%$ do fluxo de energia dentro dos sistemas decompositores, com uma contribuição relativamente menor dos detritívoros. O efeito direto da maioria dos animais na decomposição de serapilheira em florestas é muito menor que o da microflora e fatores abióticos, como a 
lixiviação. É interessante notar que as alterações no fluxo de energia e nutrientes no ecossistema são acompanhadas por alterações qualitativas e quantitativas na composição de espécies da comunidade decompositora. Assim, a diversidade de espécies está correlacionada à diversidade do microhabitat (Packham, 1992).

A decomposição, assim como a deposição de matéria orgânica, e o retorno de nutrientes ao solo florestal são os três aspectos básicos da ciclagem de nutrientes. Estudos sobre a ciclagem de nutrientes são de fundamental importância para uma melhor compreensão da auto-sustentabilidade dos ecossistemas, cujos aspectos ecológicos são ainda pouco conhecidos. 


\section{3- MATERIAIS E MÉTODOS}

\section{1- Descrição da área de estudo}

A região de Piracicaba localiza-se na depressão periférica de São Paulo, tem relevo suave ondulado e grande diversidade de solos e clima, com uma estação seca pronunciada.

O município de Piracicaba localiza-se entre as coordenadas geográficas $22^{\circ} 42^{\prime} 30^{\prime \prime S}$ e $47^{\circ} 38^{\prime} 01^{\prime \prime} W$. Situa-se a uma altitude de $554 \mathrm{~m}$ e tem uma área total de $1.312,30 \mathrm{~km}^{2}$. A temperatura no local varia de $18^{\circ} \mathrm{C} 37,5^{\circ} \mathrm{C}$; e de acordo com a classificação de Köppen, o clima da região é do tipo Cwa, com precipitaçãao anual aproximada de $1200 \mathrm{~mm}$ e estação seca durante o inverno.

A paisagem natural da região, primitivamente dominada pelas chamadas florestas mesófilas (floresta estacional semidecidual submontana) e "manchas" de cerrado, está agora reduzida a pequenos fragmentos. Seu histórico de perturbação inclui caça, extração de madeira e incêndios, sendo que esses fragmentos são geralmente inferiores a dez hectares (Viana et al, 1992).

O fragmento estudado localiza-se na Fazenda Areão, Campus da ESALQUSP, e sua área é de 4,9 ha. A vegetação presente no local é identificada como pertencendo à formação descrita, a floresta estacional semidecidual submontana (IBGE, 1992), também chamada floresta estacional semidecidual, floresta subcaducifólia tropical, ou mata mesófila semidecídua.

A vegetação na área encontra-se bastante degradada, sendo muito comum a ocorrência de clareiras de vários tamanhos, invasão por espécies oportunistas típicas de áreas com alto grau de degradação, e uma infestação por lianas desordenada em vários pontos. Muitas das árvores presentes no fragmento encontram-se danificadas, sendo que várias delas cresceram apresentando certa tortuosidade, em decorrência de uma carga de lianas excessiva, ou mesmo por efeito da competição por luz. A ocorrência de árvores mortas também é relativamente alta no local. 


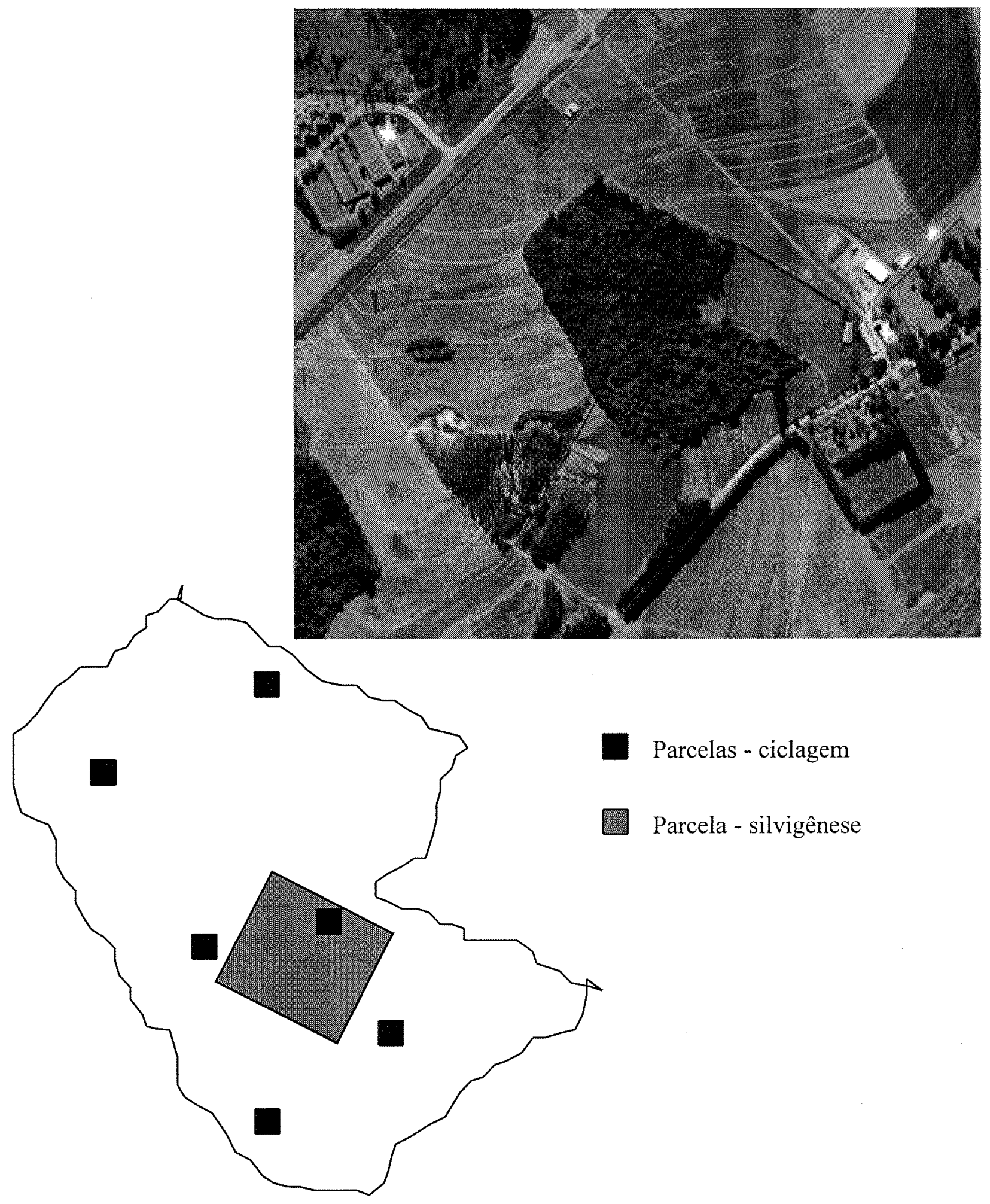

Figura 01: Foto aérea do fragmento estudado e da paisagem circundante; e croqui da área com a localização aproximada das parcelas utilizadas. 
O fragmento, localizado em área de baixada, é cercado por áreas de cultivo agrícola e um reflorestamento de espécies nativas, além de pastos abandonados e um pequeno lago; e encontra-se muito próximo à estrada principal da Fazenda.

O fragmento circunda um pequeno curso d'água (Figura 01), responsável por alagamentos que ocorrem na área na época úmida, e também abriga área de nascentes.

Segundo levantamento realizado por Vidal-Torrado \& Sparovek (1993), a área do fragmento cobre quatro tipos de solo. Esses solos foram descritos por esses autores como sendo (1) Podzólico Vermelho Amarelo, álico, Tb, A moderado, textura argilosa/muito argilos; (2) Podzólico Vermelho Escuro eutrófico, Tb, A moderado, textura argilosa/muito argilosa; (3) Podzólico vermelho escuro latossólico álico, A moderado, textura argilosa/muito argilosa; e (4)Gleissolo Eutrófico, A moderado, textura argilosa/muito argilosa ou média/médio argilosa.

Algumas características com relação à fertilidade desses solos estão descritas nas Tabelas de 01 a 04.

Os solos cobertos pelo fragmento estudado apresentam características diversas; a fertilidade do solo é variável dentro da área de estudo. Predominantemente, observa-se baixas concentrações de fósforo e potássio, e teores médios a altos de $\mathrm{Ca}$ e Mg. Os teores de matéria orgânica são altos. Os teores de $\mathrm{Al}$ variam bastante, e três dos solos descritos apresentam relativa acidez. 


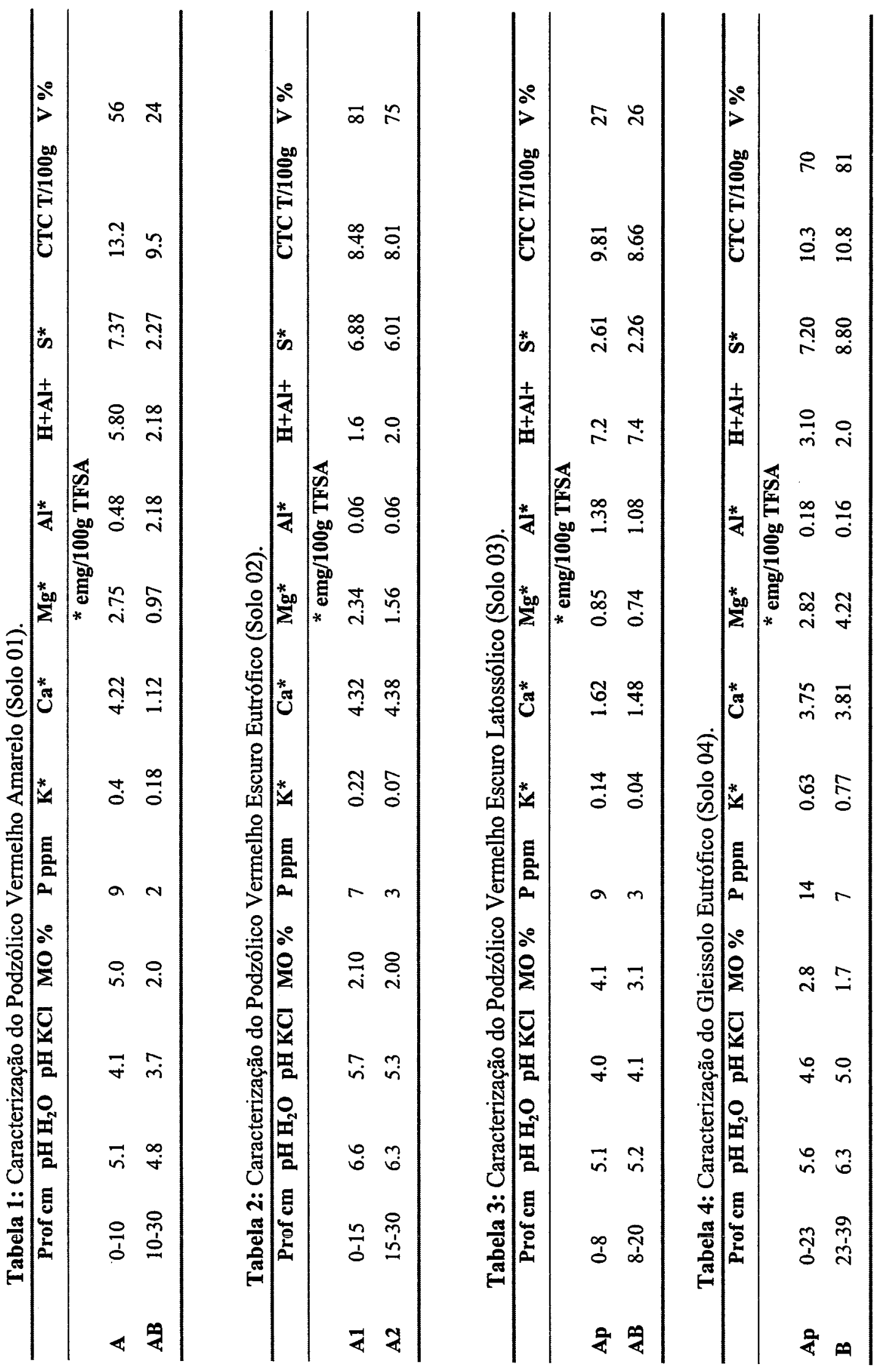




\section{2- Silvigênese}

A identificação do mosaico silvático, ou a análise silvigenética, foi realizada através do método de interceptação de linhas de inventário (transectos) sugerido por Torquebiau (1986).

Esse método utiliza transectos para o mapeamento do mosaico florestal presente na área de estudo. A interceptação desses transectos pelas projeções de copas das árvores do dossel superior da floresta (árvores dominantes) e uma análise da forma e do estado arquitetural dessas árvores permite a definição das diferentes eco-unidades presentes, e conseqüentemente a representação gráfica do mosaico ou unidade silvática.

Para o mapeamento dessas eco-unidades, foi instalada uma parcela de $50 \mathrm{x}$ $50 \mathrm{~m}$, dentro da qual foram demarcadas dez linhas, utilizando barbante (marcado de 1,0 em $1,0 \mathrm{~m}$ ), de $50 \mathrm{~m}$ de comprimento, distantes $5 \mathrm{~m}$ uma da outra, formando os transectos.

Todas as árvores dominantes, cujas projeções de copa interceptavam o barbante tinham suas coordenadas marcadas (considerando-se um sistema de eixos ortogonais). Foram incluídas também árvores localizadas fora da área de inventário, mas cujas copas também interceptavam as linhas.

As árvores do dossel são a principal barreira entre o macroclima (externo) e o microclima dentro da eco-unidade, sendo responsáveis pelo microclima interno, segundo Torquebiau,1986. Assim, só as árvores do dossel são consideradas para definir as ecounidades: o contorno das copas dessas árvores foi usado como o nível mais alto, definindo verticalmente os limites médios das eco-unidades.

Foram tomadas as seguintes medidas para cada uma das árvores consideradas: altura total, altura do fuste (ponto de inversão morfológica), DAP ("diâmetro à altura do peito" a 1,30 m de altura), diâmetro da base, além dos pontos de "projeção horizontal" da copa (distâncias perpendiculares até as linhas de inventário consideradas como sistema de eixos ortogonais) 
As árvores cuja projeção de copa interceptava as linhas foram categorizadas como árvores do presente, passado e futuro (Oldeman, 1978, 1983, 1989); e as árvores do presente foram posteriormente recategorizadas em 1A, 1B, 2A e $2 \mathrm{~B}$-respectivamente categorias 1H, 1L, 2H e 2L sugeridas por Torquebiau, 1986 (Figura 02), onde:

$1 \mathrm{~A}=$ Árvores baixas com fuste longo: árvores cuja altura total é menor que a metade da altura máxima encontrada para a área, e cuja altura do fuste é maior que a metade da altura total da árvore.

1B = Árvores baixas com fuste curto: árvores cuja altura total é menor que a metade da altura máxima encontrada e cuja altura do fuste é menor que a metade da altura total. $2 \mathrm{~A}=$ Árvores altas com fuste longo: árvores cuja altura total é maior que a metade da altura máxima encontrada e cuja altura do fuste é maior que a metade da altura total. 2B = Árvores altas com fuste curto: árvores cuja altura total é maior que a metade da altura máxima encontrada e cuja altura do fuste é menor que a metade da altura total.

Esta classificação está ligada aos conceitos de ponto de inversão morfológica e superfície de inversão ecológica. O ponto de inversão morfológica representa uma mudança de estratégia de crescimento em altura para crescimento em diâmetro e reiteração da copa. A superfície de inversão ecológica representa uma mudança drástica nas condições de crescimento para as árvores.

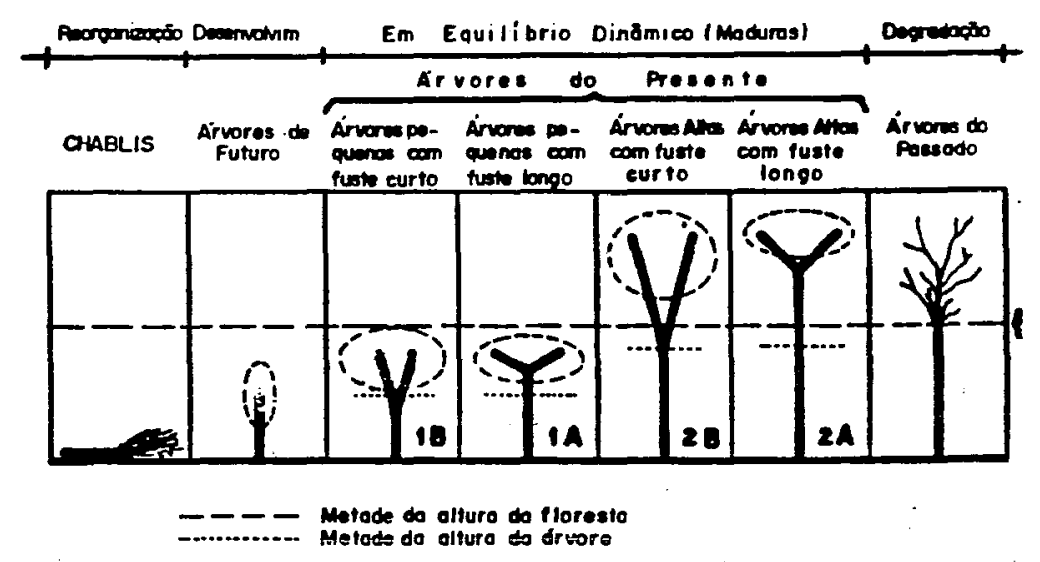

Figura 02: Chave para eco-unidades em equilibrio. 1 e $2=$ primeiro e segundo niveis do dossel, $\mathrm{A}$ e $\mathrm{B}=$ nível de inversão morfológica alto e baixo (ENGEL, 1993, baseado em TORQUEBIAU, 1986) 
A partir das projeções de copa foi elaborado um mosaico das eco-unidades presentes, unindo-se as copas adjacentes das árvores de mesma categoria. No caso de sobreposição das copas, considerou-se a área de sobreposição como pertencente à mais alta. As diferentes eco-unidades são definidas da seguinte maneira:

a) Eco-unidades em Reorganização: ocupadas por clareiras (ou "chablis" na definição de OLDEMAN, 1978, 1983, 1990).

b) Eco-unidades em Desenvolvimento: ocupadas por árvores do futuro.

c) Eco-unidades em Equilíbrio Dinâmico: ocupadas por árvores do presente:

c.1) Eco-unidades do tipo $1 \mathrm{~A}$, ocupadas por árvores do presente $1 \mathrm{~A}$.

c.2) Eco-unidades do tipo 1B, ocupadas por árvores do presente 1B.

c.3) Eco-unidades do tipo $2 \mathrm{~A}$, ocupadas por árvores do presente $2 \mathrm{~A}$.

c.4) Eco-unidades do tipo 2B, ocupadas por árvores do presente $2 \mathrm{~B}$.

d) Eco-unidades em Degradação: ocupadas por árvores do passado.

O desenho do mosaico e o cálculo das áreas das eco-unidades foram feitos pelo programa Autocad, a partir das coordenadas das copas dentro das linhas de inventário.

O resultado final desse trabalho é um mapa, uma representação gráfica do mosaico florestal presente na área de estudo. 


\section{3- CICLAGEM DE NUTRIENTES}

\subsection{1- Determinação do número e tamanho ideais de coletores}

Foram utilizados 96 coletores de $0,25 \mathrm{~m}^{2}$ de superfície, com fundo de tela de náilon com malha de $1 \mathrm{~mm}$, a $30 \mathrm{~cm}$ de altura do solo. Esses coletores foram instalados quatro a quatro, formando 24 conjuntos coletores de $1 \mathrm{~m}^{2}$ de área, distribuídos de forma casualizada em seis parcelas de $100 \mathrm{~m}^{2}, 3$ de cada lado do curso d'água que corta a área de estudo. O experimento foi instalado em abril de 1995.

A partir da distribuição dos coletores em conjunto, e da deposição mensal de serapilheira, determinou-se, através do método proposto por Pimentel-Gomes \& Chaves (1988), o tamanho e o número ideal de coletores para o presente estudo.

Por esse método, a partir de um número $\mathbf{r}$ de parcelas, subdivididas em $\mathbf{k}$ subparcelas, determina-se o tamanho ótimo das parcelas para inventário. Esse método permite que se modifique o desenho amostral sem prejuízo das estimativas de variância ou de custo de amostragem.

Considerando-se a distribuição dos coletores já descrita, considerou-se $\mathbf{r}$ como o número de conjuntos coletores de $1 \mathrm{~m}^{2}(\mathrm{r}=24)$ e $\mathbf{k}$ o número de subconjuntos, ou seja, os coletores de $0,25 \mathrm{~m}^{2}(\mathrm{k}=4)$.

O tamanho ótimo de parcelas (k') foi obtido por:

$$
\mathrm{k}^{\prime}=[(\mathrm{c} 1 / \mathrm{c} 2) *(1-\rho) / \rho]^{1 / 2}, \text { onde: }
$$

$\mathrm{c} 1$ = foi considerado como o custo de acesso (tempo gasto) a cada conjunto coletor de $1 \mathrm{~m}^{2}$.

c2 = foi considerado como o custo de coleta (tempo gasto) em cada coletor de $0,25 \mathrm{~m}^{2}$.

Neste trabalho a relação $\mathrm{c} 1 / \mathrm{c} 2$ foi considerada igual à unidade $(\mathrm{c} 1 / \mathrm{c} 2=1)$. 
Por sua vez, a estimativa $\rho$ (coeficiente de correlação intraclasse) foi obtido através da análise de variância:

\begin{tabular}{cccc}
\hline Causa da variação & GL & QM & E (QM) \\
\hline Entre coletores & n1 & V1 & $\sigma^{2}[1+(k-1) \rho]$ \\
Entre subcoletores & n2 & V2 & $\sigma^{2}(1-\rho)$ \\
\hline
\end{tabular}

Assim: $\rho=(\mathrm{V} 1-\mathrm{V} 2) /[\mathrm{V} 1+(\mathrm{k}-1) \mathrm{V} 2]$

Obtido o k', calcula-se $\mathbf{r}^{\prime}$ (número ideal de conjuntos coletores), através da equação:

$$
\mathrm{r}^{\prime}=\mathrm{r}^{*}[(\mathrm{c} 1 / \mathrm{c} 2)+\mathrm{k}] /\left[(\mathrm{c} 1 / \mathrm{c} 2)+\mathrm{k}^{\prime}\right.
$$

Através da relação entre a variância da média estimada inicial - V(m)- e final V'(m)- verificou-se qual foi a redução no erro padrão da média.

\subsection{2- Produção de serapilheira}

Para estimar a quantidade de serapilheira produzida na área de estudo, foram realizadas 12 coletas anuais, com intervalos de 30 dias, de maio de 1995 a abril de 1996.

As coletas foram realizadas da seguinte maneira: a serapilheira acumulada em cada um dos 96 coletores de $0,25 \mathrm{~m}^{2}$ foi recolhida e embalada em sacos plásticos numerados, e seca em sacos de papel em estufa à temperatura média de $60^{\circ} \mathrm{C}$

Depois de seco, o material foi pesado. Foi sorteado um coletor de $0,25 \mathrm{~m}^{2} \mathrm{em}$ cada um dos conjuntos coletores de $1 \mathrm{~m}^{2}$, que teve seu conteúdo separado em duas frações: fração Folhas e fração Outros (contendo ramos, flores, frutos, sementes e detritos). A fração Folhas foi também pesada, e o peso da outra fração estimado por diferença. 
A partir desses dados, pôde-se estimar as médias mensais e anual de serapilheira produzida pela vegetação estudada, e a porcentagem de cada uma das frações.

\subsection{3- Transferência de nutrientes através da serapilheira produzida e} eficiência de utilização de nutrientes

O material previamente sorteado e dividido nas duas frações já descritas, depois de pesado e separado, foi homogeneizado e moído em moinho tipo Wiley. Do material moído, foram retiradas alíquotas das duas frações, para cada um dos meses de coleta, para análise química em laboratório.

$\mathrm{O}$ pó resultante foi levado novamente à estufa, e seco a $50^{\circ} \mathrm{C}$.

Os elementos determinados foram os macronutrientes: Nitrogênio (N), Fósforo (P), Potássio (K), Cálcio (Ca) e Magnésio $(\mathrm{Mg})$ para cada uma das frações.

As análises foram realizadas no Laboratório de Ecologia Aplicada, do Departamento de Ciências Florestais, na ESALQ/USP.

O Nitrogênio foi determinado por destilação, seguido de titulação pelo método Microkjeldahl. As determinações do Potássio, do Cálcio e do Magnésio foram realizadas por fotometria de chama, em um espectrofotômetro de absorção atômica, e o Fósforo foi determinado pelo método do vanado-molibdato, por colorimetria (Sarruge \& Haag, 1974).

A deposição de nutrientes foi obtida multiplicando-se a biomassa seca depositada (serapilheira) pela concentração média determinada, em laboratório, para cada elemento.

A eficiência de utilização desses nutrientes foi determinada através da relação entre a biomassa de serapilheira produzida e a quantidade de nutrientes transferidos por essa fração, como proposto por Vitousek (1982). 


\subsection{4- Serapilheira acumulada e taxa de decomposição}

A serapilheira acumulada sobre o solo foi estimada em duas coletas, uma em novembro de 1995 (final da estação seca) e outra em março de 1996 (final da estação chuvosa), onde foram coletadas 6 amostras (uma por parcela), utilizando-se um quadrado de madeira de $0,25 \mathrm{~m}^{2}$. Para obtenção dessas amostras, coletou-se toda a manta existente sobre o solo.

O material coletado foi seco em estufa, juntamente com a serapilheira retirada dos coletores, a uma temperatura média de $60^{\circ} \mathrm{C}$.

A taxa de decomposição da serapilheira foi estimada a partir da equação proposta por OLSON (1963):

$$
\frac{L}{X s s}=K \text {, onde: }
$$

$\mathrm{L}=$ quantidade de serapilheira produzida anualmente $\left(\mathrm{g} / \mathrm{m}^{2}\right)$,

$\mathrm{X}_{\mathrm{ss}}=$ média anual de serapilheira acumulada sobre o solo $\left(\mathrm{g} / \mathrm{m}^{2}\right)$,

$\mathrm{K}=$ constante de decomposição para situações de equilíbrio dinâmico.

Calculou-se também, a partir do valor de $\mathrm{K}$, o tempo médio de renovação, estimado por $1 / \mathrm{K}$.

Foram calculados ainda os tempos necessários para o desaparecimento de 50\% e 95\% da serapilheira, segundo Shanks \& Olson (1961):

$$
\begin{aligned}
& \text { t } 0,5=e_{0,5}^{-k t} \text { ou t } 0,5=0,693 / K \\
& \text { t } 0,05=3 / K
\end{aligned}
$$




\section{4- RESULTADOS E DISCUSSÃo}

\section{1- Silvigênese}

A área total amostrada foi de $2.530,53 \mathrm{~m}^{2}$, e o número total de árvores em pé que interceptaram as linhas de inventário foi de 124, o que corresponde a 496 árvores/ha.

Comparativamente, essa densidade arbórea é maior do que as encontradas por Engel \& Prado (1992) numa mata de tabuleiros no Espírito Santo e por CardosoLeite (1995) em três parcelas diferentes numa mata mesófila semidecídua em São Roque- SP, os dois únicos trabalhos realizados no Brasil utilizando-se esta metodologia. Isso indica que aparentemente as árvores do fragmento estudado têm copas menores, ou seja, ocupam uma área menor que as dos referidos trabalhos. Essa informação é confirmada pelas dimensões das árvores amostradas. A altura máxima encontrada foi de $20 \mathrm{~m}$, bem menor que as encontradas por esses outros autores, mas condizente com o esperado para esse tipo de vegetação (floresta estacional semidecidual).

As árvores dominantes apresentaram grande heterogeneidade no tamanho $\mathrm{e}$ forma das copas. É bem visível também uma grande assimetria entre elas. Isso ocorre porque cada árvore deve ser capaz de ocupar pequenas aberturas existentes durante 0 processo de expansão das copas, através de uma maior ou menor habilidade reiterativa (Engel \& Prado, 1992).

Em alguns trechos, ocorreram espaços vazios entre as projeções das copas das árvores. Apenas em alguns pontos houve sobreposição, o que demonstra que o espaçamento utilizado entre as linhas foi satisfatório.

Torquebiau (1986) afirma que usando a metade da altura das árvores como referência, pode-se diferenciar duas arquiteturas opostas de acordo com o nível de inversão. As alturas variáveis dos níveis de inversão na floresta refletem as condições de crescimento das árvores presentes. Árvores com ponto de inversão acima da metade de sua altura total são aquelas que atingiram recentemente o dossel ou que cresceram em uma "chaminé ecológica", ou seja, em uma abertura estreita do dossel até o piso. Por 
outro lado,árvores que cresceram a céu aberto ou em clareiras grandes encontram um nível energético suficiente para que entrem em um processo de reiteração muito cedo, desenvolvendo fuste baixo e copa ampla, e seu ponto de inversão está situado abaixo da metade da altura total (Engel, 1993).

Das árvores amostradas, 13 são do passado, 78 do presente e 33 do futuro, respectivamente $10 \%, 63 \%$ e $27 \%$ (Tabela 05 ).

Dentre as árvores do presente, 30 pertencem à categoria $1 \mathrm{~A}, 27$ à $2 \mathrm{~A}, 13$ à $1 \mathrm{~B}$ e 08 à 2B . A grande maioria delas (73\%) apresentou fuste alto, ou seja, reiteração acima da superficie de inversão morfológica da floresta, o que indica que provavelmente atingiram há pouco tempo o dossel, ou que cresceram em pequenas aberturas. Apenas 21 árvores, representando $27 \%$ das árvores amostradas, demonstram ter crescido em ambientes mais abertos (apresentam fuste baixo), provavelmente em clareiras ou próximas às bordas (Tabela 06 ).

Muitas das árvores presentes na área estudada cresceram com alterações arquiteturais, provavelmente em decorrência do peso e da competição por luz causados pela alta infestação por lianas sobre alguns indivíduos. Porém, essas alterações não parecem ter prejudicado o desenvolvimento ou a sanidade desses indivíduos, já que várias dessas árvores foram consideradas árvores do presente, por se encontrarem bastante vigorosas e com grandes expansões laterais das copas. Apesar de "tortos" até determinada altura, quando passaram a apresentar uma capacidade reiterativa normal, esses indivíduos parecem ter-se adaptado bem aos fatores condicionantes do meio.

A Figura 03 mostra a distribuição de alturas das árvores do presente e do futuro. Nota-se que, ao contrário do resultado obtido por Torquebiau (1986), Engel \& Prado (1992) e Cardoso-Leite (1995), onde a maior parte dos indivíduos do presente concentrava-se acima da altura correspondente à superficie de inversão da floresta, os da área de estudo encontram-se distribuídos por quase todas as classes de altura 
representadas, concentrando-se abaixo dos $10 \mathrm{~m}$ (metade da altura máxima encontrada), principalmente de 4 a $6 \mathrm{~m}$ de altura.

Tabela 05: Número e proporção de árvores encontradas nas diferentes categorias:

\begin{tabular}{ccc}
\hline Categoria & $\mathbf{N}^{\circ}$ & $\%$ \\
\hline Árvores do presente & 78 & 63 \\
Árvores do passado & 13 & 10 \\
Árvores do futuro & 33 & 27 \\
Total & $\mathbf{1 2 4}$ & $\mathbf{1 0 0}$ \\
\hline
\end{tabular}

Tabela 06: Distribuição das árvores do presente em diferentes categorias:

\begin{tabular}{ccc}
\hline Categoria & $\mathbf{N}^{\circ}$ de indivíduos & $\%$ \\
\hline 1 A & 30 & 38 \\
1 B & 13 & 17 \\
2 A & 27 & 35 \\
2 B & 08 & 10 \\
Total & $\mathbf{7 8}$ & $\mathbf{1 0 0}$ \\
\hline
\end{tabular}

Tabela 07: Estrututura e composição de eco-unidades determinadas por mapeamento no campo.

\begin{tabular}{cccccccc}
\hline Variável & Reorg. & Desenvolv. & 1 A & 1 B & 2 A & 2 B & Degrad. \\
\hline $\mathrm{N}^{\circ}$ de e.u. & 08 & 15 & 09 & 06 & 09 & 05 & 07 \\
$\mathrm{~N}^{\circ}$ de e.u./ha & 32 & 60 & 36 & 24 & 36 & 20 & 28 \\
Tamanho médio $\left(\mathrm{m}^{2}\right)$ & 34.49 & 18.23 & 57.14 & 28.09 & 77.09 & 95.18 & 18.36 \\
Área total $\left(\mathrm{m}^{2}\right)$ & 275.99 & 273.47 & 514.3 & 168.52 & 693.80 & 475.93 & 128.53 \\
Área (\%) & 10.9 & 10.8 & 20.32 & 6.66 & 27.42 & 18.8 & 5.1 \\
\hline
\end{tabular}

Isso pode ser explicado pelo fato de muitas árvores do presente pertencerem a espécies presentes em estratos mais baixos, que não atingiram grandes alturas e que provavelmente foram inseridas entre as "dominantes" devido a distúrbios que expuseram suas copas, não sofrendo sobreposição de indivíduos mais altos.

Já a distribuição das árvores do futuro, assemelha-se à esperada, pois esses indivíduos concentram-se em classes abaixo da superfície de inversão. Segundo Engel \& 
Prado (1992), abaixo da altura da superfície de inversão os níveis energéticos não são suficientes para que a árvore passe da categoria do futuro para a do presente.

Das clareiras registradas na área de estudo, poucas foram formadas pela queda de árvores inteiras, a maioria por galhos quebrados ou queda de partes de árvores mortas em pé. Segundo Oldeman (1978), as árvores mortas em pé causam as mesmas mudanças energéticas que na clareira do "chablis", mas mais gradualmente. Das clareiras consideradas, muitas encontram-se totalmente cobertas por cipós, permitindo uma menor incidência de radiação, e muito provavelmente ocasionando uma taxa de regeneração diferente das demais.

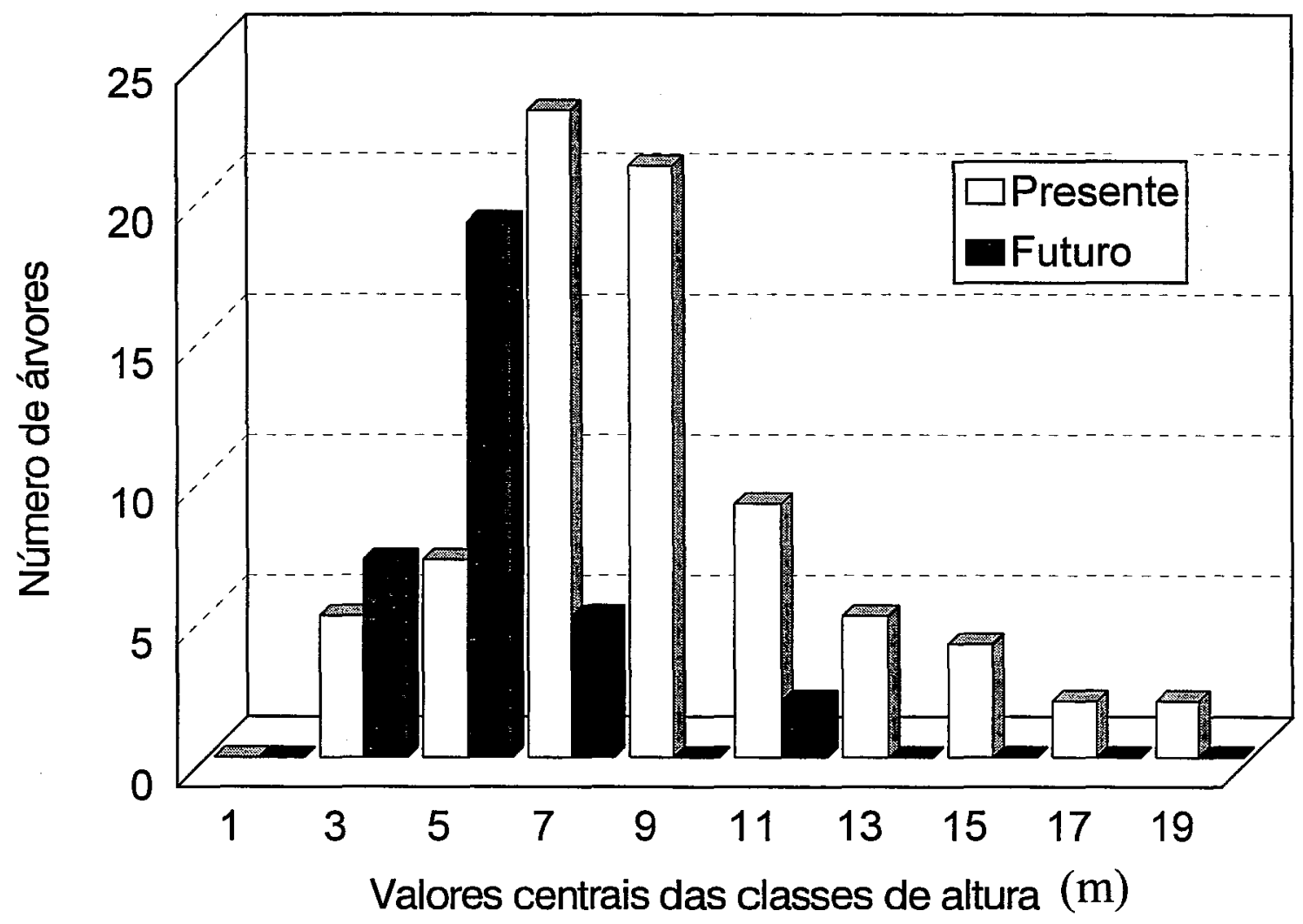

Figura 03: Distribuição de alturas das árvores do presente e do futuro (freqüências absolutas). 
As eco-unidades presentes não são eco-unidades muito grandes; com tamanho médio de $46,94 \mathrm{~m}^{2}$ (Tabela 07). Oldeman (1983) sugere que o tamanho da eco-unidade está diretamente relacionado à sua origem, sendo que eco-unidades pequenas a intermediárias são resultado de queda de árvores ou de morte destas em pé.

Uma grande porcentagem da área $(73,2 \%)$ é ocupada por eco-unidades em equilíbrio dinâmico $1 \mathrm{~A}, 1 \mathrm{~B}, 2 \mathrm{~A}$ e $2 \mathrm{~B}$.

No trabalho de Torquebiau (1986), mais de 50\% da área era ocupada por ecounidades $2 \mathrm{~A}$, consideradas por esse autor como correspondentes à fase madura da floresta. $\mathrm{O}$ autor considerou a existência de uma matriz de eco-unidades $2 \mathrm{~A}$ onde as demais estariam inseridas.

No presente estudo,porém, não há um predomínio de eco-unidades $2 \mathrm{~A}$, e embora essas apareçam em grande número, as porcentagens das eco-unidades $1 \mathrm{~A}$ e $2 \mathrm{~A}$ (tanto em área quanto em número) são muito próximas (respectivamente $20,32 \%$ e $27,42 \%$ da área).

As porcentagens de $1 \mathrm{~A}$ surpreendem, por serem muito superiores às encontradas em outros trabalhos (Tabela 08). Segundo Engel \& Prado (1992), as eco-unidades 1A representam, provavelmente, áreas de distúrbios mais recentes no dossel, que expuseram árvores do estrato médio desenvolvidas inicialmente à sombra. Torquebiau (1986) afirma que as eco-unidades $1 \mathrm{~A}$ e 1B devem resultar de distúrbios no dossel superior, mas também podem ser um sinal de processos silvigenéticos recentes se essas árvores se desenvolveram sob uma matriz florestal baixa; essas eco-unidades são constituídas de árvores que raramente atingem grandes alturas.

As eco-unidades $2 \mathrm{~B}$ apresentaram porcentagens bem próximas às $1 \mathrm{~A}$, sendo superiores às encontradas por outros autores. As árvores que compõem essas ecounidades podem ter se desenvolvido em clareiras relativamente grandes, o que ocasionou uma superfície de inversão mais baixa. 
Eco-unidades em desenvolvimento e em reorganização apresentaram porcentagens de área semelhantes. O número de eco-unidades em desenvolvimento, porém, é bem alto (Tabela 07). As eco-unidades em reorganização ocuparam uma área relativamente grande $(10,9 \%)$, duas vezes maior que na área de mata mesófila semidecídua estudada por Cardoso-Leite (1995) em São Roque. Altas porcentagens de ecounidades em reorganização, desenvolvimento e degradação podem demonstrar a ocorrência de uma dinâmica intensa na área.

É importante notar que duas das eco-unidades em reorganização representam uma grande parte da área ocupada por eco-unidades desse tipo, enquanto que todas as demais podem ser consideradas pequenas; muito provavelmente porque essas duas são formadas quase que exclusivamente por apenas uma clareira, o que pode ser em decorrência de perturbação mais forte devido a uma maior proximidade das bordas do fragmento.

Torquebiau (1986) afirma que uma alta proporção de eco-unidades em reorganização podem representar uma dinâmica mais efetiva; e que porcentagens altas de eco-unidades $2 \mathrm{~A}$ e em reorganização podem significar uma alta taxa de renovação, ou um processo regenerativo rápido na área.

A taxa de renovação está relacionada com a freqüência de ocorrência de clareiras na floresta.

As eco-unidades em degradação ocupam 5,1\% da área estudada, superior (ainda que pouco) às taxas encontradas em outros trabalhos, compreendendo as eco-unidades mais raras na área.

Cardoso Leite (1995) sugere intervalos padrão para as porcentagens de ecounidades para florestas tropicais e subtropicais brasileiras em áreas cujas características básicas da vegetação como a fisionomia e a diversidade foram menos perturbadas, baseando-se nos estudos realizados em São Roque- SP e Linhares-ES (Tabela 09). 
Tabela 08: Porcentagem de área ocupada pelos diferentes tipos de eco-unidades, no fragmento estudado e em outros trabalhos:

\begin{tabular}{cccccccc}
\hline Local & Reorg. & Desenv. & 1 A & 1 B & 2 A & 2 B & Degrad. \\
\hline Indonesia* & 4.8 & 12.4 & 2.8 & 0.3 & 66.8 & 11.4 & 1.4 \\
Linhares-ES** & 3.2 & 9.4 & 5.5 & 11.7 & 42.4 & 23.4 & 4.3 \\
São Roque-SP*** & 5.3 & 6.36 & 7.9 & 2.9 & 57.0 & 16.0 & 3.46 \\
Piracicaba-SP**** & 10.9 & 10.8 & 20.32 & 6.66 & 27.42 & 18.8 & 5.1 \\
\hline
\end{tabular}

* Floresta de Dipterocarpaceaes (TORQUEBIAU, 1986), ${ }^{* *}$ Floresta Pluvial Atlântica (ENGEL \& PRADO, 1992), ${ }^{* * *}$ Mata Mesófila Semidecídua (CARDOSO-LEITE, 1995), ${ }^{* * * *}$ Mata Mesófila Semidecídua (Este estudo)

As porcentagens encontradas na área de estudo divergem bastante dos padrões encontrados para os dois trabalhos, realizados em áreas aparentemente menos perturbadas e mais maduras.

Como demonstrado na Tabela 07 , as porcentagens de eco-unidades em degradação, desenvolvimento e em equilíbrio dos tipos $1 \mathrm{~B}$ e $2 \mathrm{~B}$ enquadram-se nos padrões propostos pela autora.

As porcentagens de eco-unidades em reorganização e do tipo 1A foram muito altas e as de eco-unidades do tipo $2 \mathrm{~A}$ muito baixas, demonstrando que a área não apresenta um equilíbrio arquitetural avançado.

Tabela 09: Intervalos-padrão sugeridos para as porcentagens das diferentes eco-unidades em florestas.

\begin{tabular}{cc}
\hline Categorias de eco-unidades & (\%) \\
\hline Degradação e reorganização & 3.2 a 5.3 \\
Desenvolvimento, 1 A e 1 B & 2.9 a 11.7 \\
2 A & 42.0 a 57.0 \\
2 B & 16.0 a 23.4 \\
\hline
\end{tabular}

Observando-se o mosaico florestal representado, pode-se notar que as ecounidades em desenvolvimento, assim como as em reorganização,ocorrem principalmente a oeste da parcela utilizada; enquanto que as em degradação encontram-se presentes 
principalmente na face leste. Mesmo considerando-se uma área pequena, pode-se concluir que ocorreram processos silvigenéticos distintos dos dois lados, e que na face leste a vegetação se encontra em estádios silvigenéticos mais "avançados" (demonstrado pelo maior número de eco-unidades em equilíbrio dinâmico), não tendo sofrido tantas perturbações recentes.

$\mathrm{Na}$ face oeste, o fragmento sofre maior influência externa; parece sofrer um maior efeito de borda, em decorrência de estar próximo a áreas de cultura intensiva, onde alterações no meio são constantes. A taxa de renovação parece ser maior na face oeste, $\mathrm{e}$ as perturbações mais recentes aparentemente também foram maiores nessa área. 


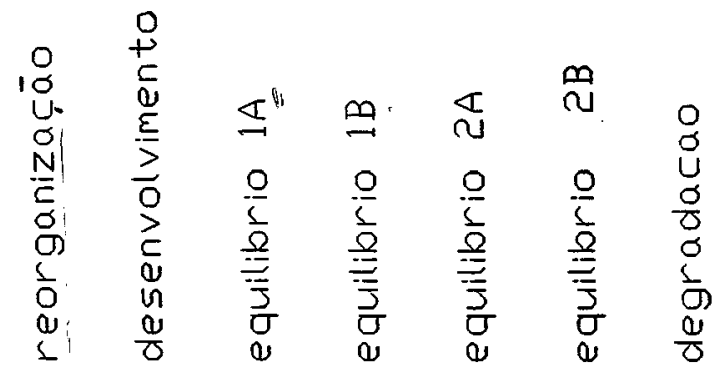

$$
\begin{aligned}
& \begin{array}{lllllll}
\varepsilon & \varepsilon & \varepsilon & \varepsilon & \varepsilon & \varepsilon & \varepsilon \\
0 & 0 & 0
\end{array}
\end{aligned}
$$

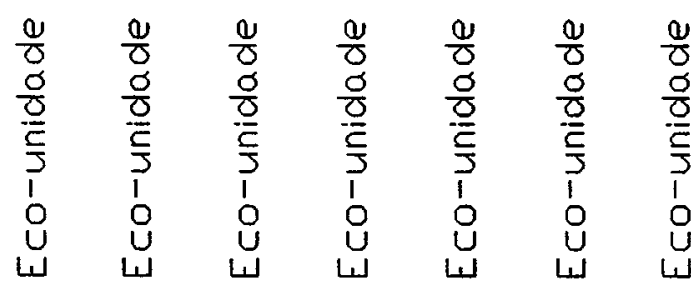

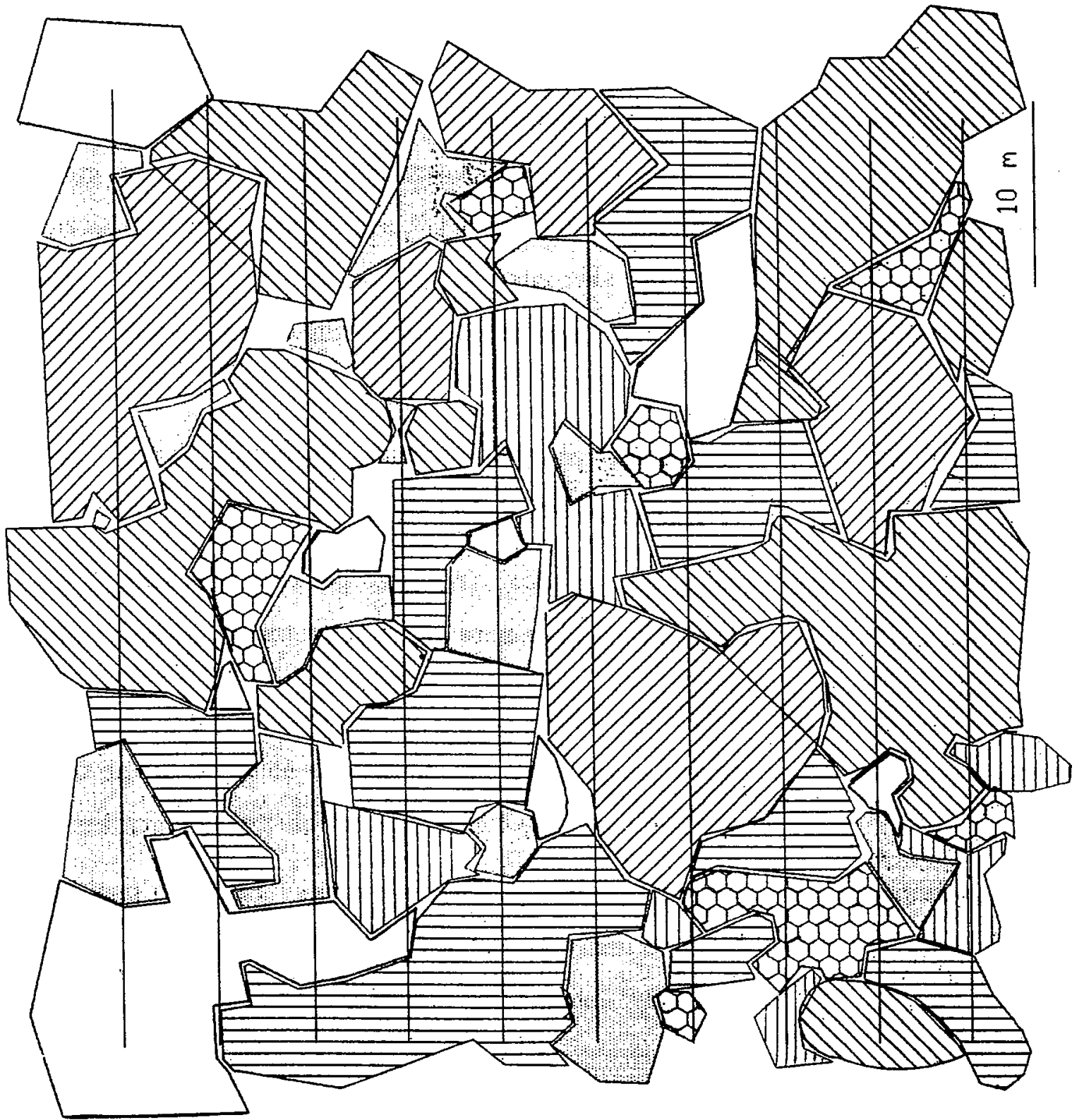




\section{2- Ciclagem de nutrientes}

\subsection{1-Determinação do número e do tamanho ideais de coletores}

Segundo Proctor (1983), ocorrem problemas na comparação dos dados em estudos sobre ciclagem de nutrientes, em função das diferentes metodologias empregadas para obtenção do mesmo tipo de resultado. Esse autor afirma que, entre outros fatores, a forma, o tamanho e o número de coletores podem afetar significativamente os resultados obtidos.

No estudo realizado por Pimentel-Gomes \& Chaves (1988), aborda-se o problema do tamanho ótimo da parcela através de amostragem de duplo estádio, com o auxílio do coeficiente de correlação intraclasse $(\rho)$ entre subparcelas dentro de parcelas. Considera-se ótimo o tamanho da parcela que minimize a variância da estimativa da média, para um custo fixo de amostragem. Segundo Pimentel-Gomes \& Couto (1985) isso equivale a tornar mínima a área do experimento, para obter uma variância dada para a média de cada tratamento. Esses autores afirmam ser possível reduzir significativamente a área destinada a experimentos florestais, sem afetar a precisão do experimento.

A Tabela 10 mostra os valores obtidos para $\mathbf{k}^{9}$ (tamanho ótimo) e para $\mathbf{r}^{\prime}$ (número ótimo) de coletores para o período de estudo.

Quanto mais próximo de zero (0) estiver o valor de $\rho$, maior variação ocorre dentro das parcelas, portanto maior deve ser o tamanho das parcelas utilizadas.

Os valores estimados para $\rho$ variam para cada mês, obviamente acompanhando a variação na deposição de serapilheira através do ano. Entretanto os valores estimados não demonstram uma grande variação dentro dos conjuntos coletores.

Para se obter a variância mínima da média da amostra deve-se utilizar apenas um subcoletor por conjunto coletor. Assim, o tamanho ótimo de coletor para esse estudo seria de $0,25 \mathrm{~m}^{2}$ ( área correspondente a cada um dos subcoletores). 
Tabela 10: Valores calculados de $\rho$ (coeficiente de correlação intraclasse), k' (tamanho ótimo de coletores) e r' (número ótimo de coletores) para os meses de coleta.

\begin{tabular}{ccccc}
\hline Mês & $\rho$ & k' calculado & r' calculado & $\begin{array}{c}\text { Redução no erro padrão } \\
\text { da média (\%) }\end{array}$ \\
\hline $\mathbf{M}$ & 0.68515 & 0.67789 & 60 & 47.63 \\
$\mathbf{J}$ & 0.56977 & 0.86896 & 60 & 40.94 \\
$\mathbf{J}$ & 0.37698 & 1.28556 & 60 & 24.92 \\
$\mathbf{A}$ & 0.80279 & 0.49563 & 60 & 53.05 \\
$\mathbf{S}$ & 0.64898 & 0.73544 & 60 & 45.70 \\
$\mathbf{O}$ & 0.88459 & 0.36119 & 60 & 56.20 \\
$\mathbf{N}$ & 0.60402 & 0.80968 & 60 & 43.10 \\
$\mathbf{D}$ & 0.68484 & 0.67837 & 60 & 47.61 \\
J & 0.86392 & 0.39688 & 60 & 55.45 \\
F & 0.85219 & 0.41647 & 60 & 55.01 \\
$\mathbf{M}$ & 0.68829 & 0.67296 & 60 & 47.79 \\
$\mathbf{A}$ & 0.69388 & 0.66420 & 60 & 48.07 \\
\hline
\end{tabular}

Para o cálculo do número de ideal coletores utilizou-se o valor aproximado de $k^{\prime}\left(k^{\prime}=1\right)$, resultando em 60 coletores de $0,25 \mathrm{~m}^{2}$.

Esses resultados são contrastantes com o encontrado em literatura, como por exemplo Schliter et al (1993), Poggiani \& Monteiro Júnior (1990), Morellato (1992), Pagano (1989) e César (1993) que utilizaram de 21 a 36 coletores, todos com $1 \mathrm{~m}^{2}$ de área. Já Meguro (1979) utilizou 24 coletores de $0,36 \mathrm{~m}^{2}$.

Cabe ressaltar que o número de coletores a ser utilizado em estudos de ciclagem em florestas naturais está intrinsicamente relacionado com a variabilidade inerente a cada floresta.

Porém, a representatividade desta variabilidade pode ser melhor demonstrada utilizando-se coletores menores e em maior número.

Isso foi verificado no presente estudo, onde 60 coletores de $0,25 \mathrm{~m}^{2}$ forneceriam melhores estimativas de deposição do que os 24 coletores de $1 \mathrm{~m}^{2}$ utilizados, acarretando em média numa redução de $47 \%$ no erro padrão da média. 
Conclui-se portanto que, em quaisquer trabalhos que utilizem coleta de serapilheira, deve ser utilizado um maior número de coletores, com uma menor área. Os dados sugerem que como padrão sejam utilizados coletores de $0,25 \mathrm{~m}^{2}$.

\subsection{2-Produção de serapilheira:}

A produção de serapilheira foi estimada em $14.715,97 \mathrm{~kg} \cdot \mathrm{ha}^{-1} \cdot \mathrm{ano}^{-1}$, como pode ser visualizado na Tabela 11 .

Segundo Brown \& Lugo (1990), em florestas secundárias, espera-se altas taxas de produção, acima de 13 t.ha ${ }^{-1}$.ano ${ }^{-1}$ para florestas de doze a quinze anos. Segundo esses mesmos autores, nas florestas secundárias com menos de vinte anos, a produção de serapilheira é uma das mais altas.

Tabela 11: Dados de deposição de serapilheira (frações Folhas, Outros e Total) no decorrer do ano de estudo, em em kg.ha ${ }^{-1}$.

\begin{tabular}{llll}
\hline & FOLHAS & OUTROS & TOTAL \\
\hline Maio & 473.30 & 267,83 & 741,13 \\
Junho & 507.37 & 234,07 & 741,43 \\
Julho & 545,10 & 274,60 & 819,70 \\
Agosto & 1043,70 & 225,62 & 1269,32 \\
Setembro & 1941,85 & 743,67 & 2685,52 \\
Outubro & 1417,33 & 1298,87 & 2716,20 \\
Novembro & 652,00 & 216,50 & 868,5 \\
Dezembro & 898,62 & 205,07 & 1103,68 \\
Janeiro & 795,02 & 164,93 & 959,95 \\
Fevereiro & 969,62 & 260,68 & 1230,30 \\
Março & 697,15 & 114,20 & 811,35 \\
Abril & 592,27 & 176,62 & 768,88 \\
TOTAL & 10533,32 & 4182,65 & 14715,97 \\
\hline
\end{tabular}

O valor encontrado, embora se encontre entre os valores médios para florestas subtropicais e tropicais levantadas por Brown \& Lugo (1982), que variam de 1 a 15,3 t.ha ${ }^{-1}$.ano ${ }^{-1}$, suplanta todos os estudos anteriores realizados em florestas mesófilas do Estado de São Paulo, podendo ser considerado alto (Tabela 12). 
A alta produção de serapilheira estimada pode ser explicada pelo grau de perturbação da área de estudo. O fragmento é pequeno, e sua área é recortada, sofrendo muito as consequências por efeito de borda e pelas características de utilização do entorno.

Schlitter et al (1993) julgam haver correspondência entre a produção de serapilheira e o grau de perturbação. Historicamente, as áreas com maior produção, como as estudadas por Meguro et al (1979a) e Diniz (1987) são as mais perturbadas pela ação antrópica, apresentando alta infestação por lianas e alto número de clareiras. A área analisada no presente estudo enquadra-se perfeitamente nessa caracterização; no fragmento existe alta incidência de lianas, e a ocorrência de clareiras é elevada, como pode-se verificar através da análise silvigenética.

Laurance (1991), estudando o efeito de borda em fragmentos florestais tropicais, encontrou dados que demonstram grandes danos no dossel e subdossel da floresta, além de uma abundância excepcional de lianas.

Alguns autores, avaliando a deposição de material vegetal em florestas tropicais, destacam a importância das lianas. Hegarty (1992), numa floresta da Austrália, observou que a contribuição das lianas na produção de folhedo foi quinze vezes maior que a das árvores.

Gentry $^{2}$ citado por Engel (1993), explica a maior razão entre produção de serapilheira/produção de madeira em florestas tropicais pela proporção maior de lianas (em torno de dez vezes a das florestas temperadas). Já Burghouts et al (1994), estudando o efeito da heterogeneidade de espécies sobre a queda de serapilheira numa floresta na Malaysia afirma que, em áreas exploradas, a queda de folhas foi dominada por lianas e espécies arbóreas pioneiras.

\footnotetext{
${ }^{2}$ GENTRY, A.H. 1983 Lianas and the paradox of contrasting latitudinal gradients in wood and litter production Tropical Ecology, Varanasi 24 (10) 63-67
} 
Burnham (1994), analisando a serapilheira usada para estudos em florestas tropicais, constatou que $1 / 3$ das espécies que contribuíram na produção desse material era de epífitas e lianas herbáceas e lenhosas.

Pagano (1989a) conclui que as lianas, muito provavelmente, são responsáveis pela alta produção de folhedo em florestas tropicais, e que valores diferentes de deposição encontrados para o mesmo tipo de vegetação devem estar estreitamente relacionados ao grau de infestação, sendo esse muitas vezes dependente do grau de perturbação da floresta.

Cabe ressaltar aqui a importância desse grupo de plantas, que em algumas épocas do ano substituem as árvores na função de manutenção da ciclagem de nutrientes (as lianas padrões fenológicos - picos de floração e frutificação, bem como queda de folhas- diferenciados das árvores), principalmente em locais perturbados, com baixa densidade de indivíduos arbóreos.

A deposição de biomassa alcançou seu valor máximo em outubro, seguido de

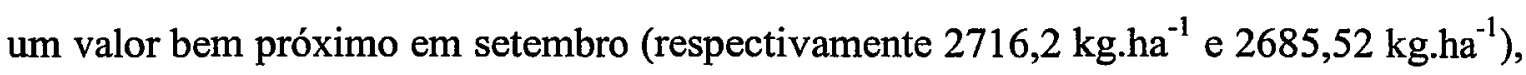
demonstrando que a deposição apresentou características sazonais. Agosto foi o terceiro mês em deposição $\left(1269,32 \mathrm{~kg} \cdot \mathrm{ha}^{-1}\right)$. Os meses de agosto, setembro e outubro representaram 45,3\% da biomassa depositada (Figura 05).

Segundo Golley (1983) em florestas ajustadas à estação seca, geralmente a queda de serapilheira é máxima nesse período. Meguro et al (1979) afirma que a queda de folhas em florestas tropicais é, de modo geral, contínua mas variável, apresentando um pico máximo na estação seca.

Os meses de agosto e setembro marcam o final da estação seca. Correspondem a respectivamente ao primeiro e quarto meses mais secos do ano. $\mathrm{O}$ mês de outubro marca o início da época de chuvas, sendo o quarto mês do ano em precipitação.

No mês de outubro, ocorreram chuvas muito fortes, sendo que apenas três dias de chuva representaram mais da metade da precipitação total nesse mês. A precipitação 
média no mês de outubro foi muito superior à precipitação do mesmo período nos anos anteriores, portanto atípica. A ocorrência de uma forte tempestade poucos dias antes da coleta nesse mês pode ter sido responsável pela deposição máxima.

Morellato (1992b) também afirma que o pico de deposição em sua área de estudo ocorreu no final da estação seca (agosto-setembro), decaindo em outubro. Provavelmente, não fosse a ocorrência da tempestade, os picos de deposição nos dois estudos seriam coincidentes.

Os dois meses com maior deposição de serapilheira foram os meses com dados de ventos com as maiores velocidades, que muito provavelmente, derrubaram altas quantidades de material vegetal. 


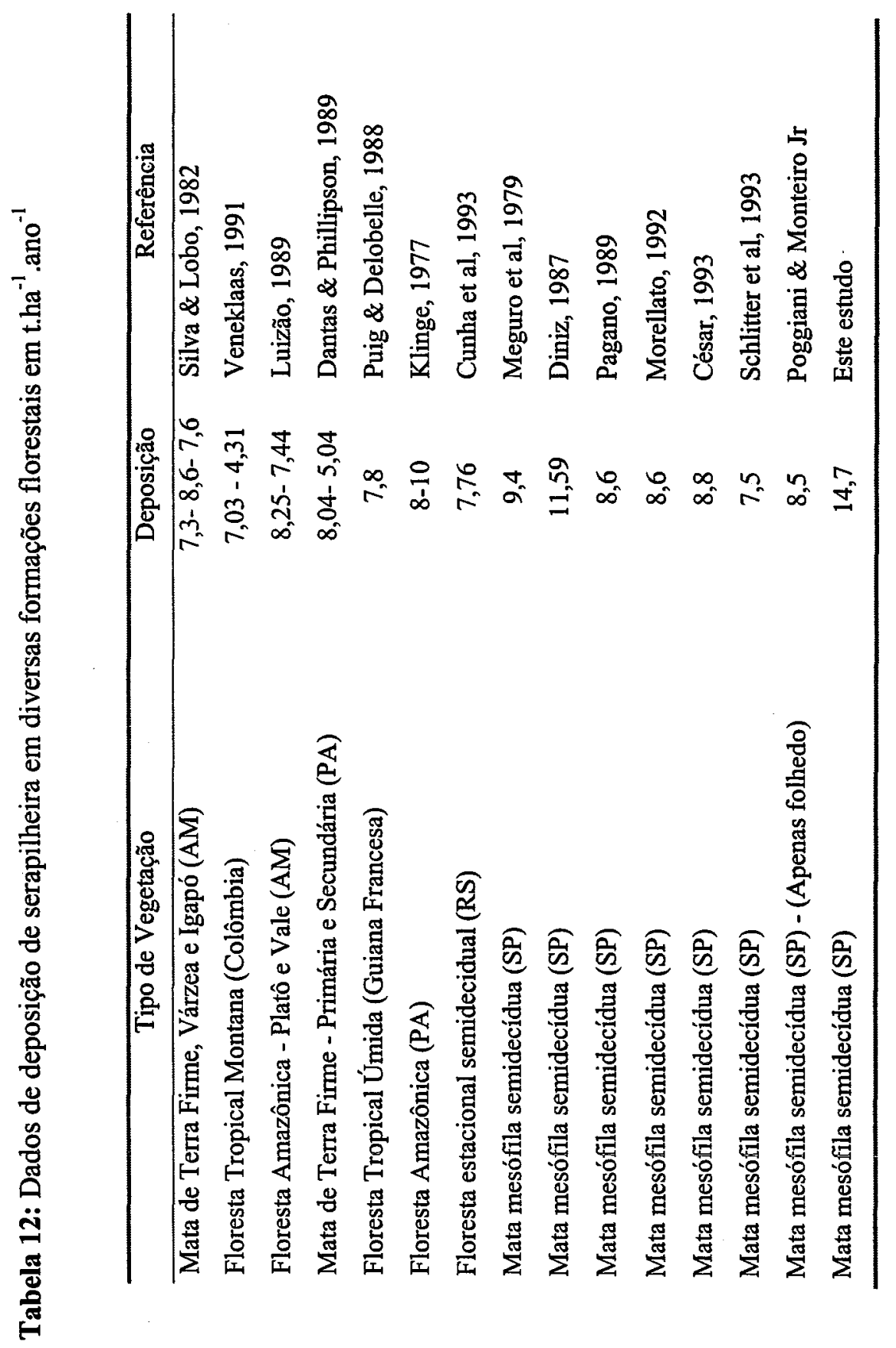


$\mathrm{Na}$ área de estudo, é muito comum a formação de emaranhados de cipós sobre e ao redor das copas das árvores, formando como que "bolsas", onde se acumula muito material vegetal. Quando há queda dessas bolsas, o que provavelmente ocorreu devido à ação do vento, há um aumento significativo na quantidade de material depositado.

No mês de fevereiro, houve um ligeiro aumento, com relação aos dois meses anteriores, tanto na biomassa total quanto nas duas frações. $O$ mês de fevereiro é o quarto mês em biomassa depositada. Esse mês também foi caracterizado por alta precipitação e ventos relativamente fortes.

Resultados semelhantes foram encontrados por Luizão (1989) numa floresta na Amazônia Central. O autor afirma que uma forte tempestade foi responsável por uma grande produção de serapilheira em um dos meses de estudo, e provavelmente, de uma queda na produtividade no mês seguinte. Num dos anos de observação, o pico de deposição foi num mês de precipitação elevada, seguindo vários dias de seca. $\mathrm{O}$ autor conclui que existe alguma dependência na queda de serapilheira e de material foliar com relação às variações no regime de chuva.

Segundo Brinkman ${ }^{3}$, citado por Luizão (1989), as condições ecológicas na floresta tropical não são controladas pelas variações na quantidade total de chuvas mensais ou sazonais somente, mas muito mais pelo impacto da precipitação, e da densidade e frequiência dos períodos sem chuva.

Luizão (1989) cita também em seu trabalho a ocorrência de um pico secundário de produção nos meses chuvosos, em um outro ano, semelhantemente ao ocorrido em fevereiro, no presente estudo.

Herbohn \& Congdon (1993) também descreve a influência da ocorrência de tempestades na queda de serapilheira. Ventos fortes e chuvas pesadas, associadas a um ciclone resultaram em aumentos significantes na queda de serapilheira. Os autores

\footnotetext{
${ }^{3}$ BRINKMAN, W.L.F. Studies on hydrogeochemistry of a tropical lowland forest system GeoJournal 11 (1): 89-101, 1985
} 
acreditam que os ventos fortes devem ter sido suficientes para remover grandes quantidades de material lenhoso que estaria retido no dossel.

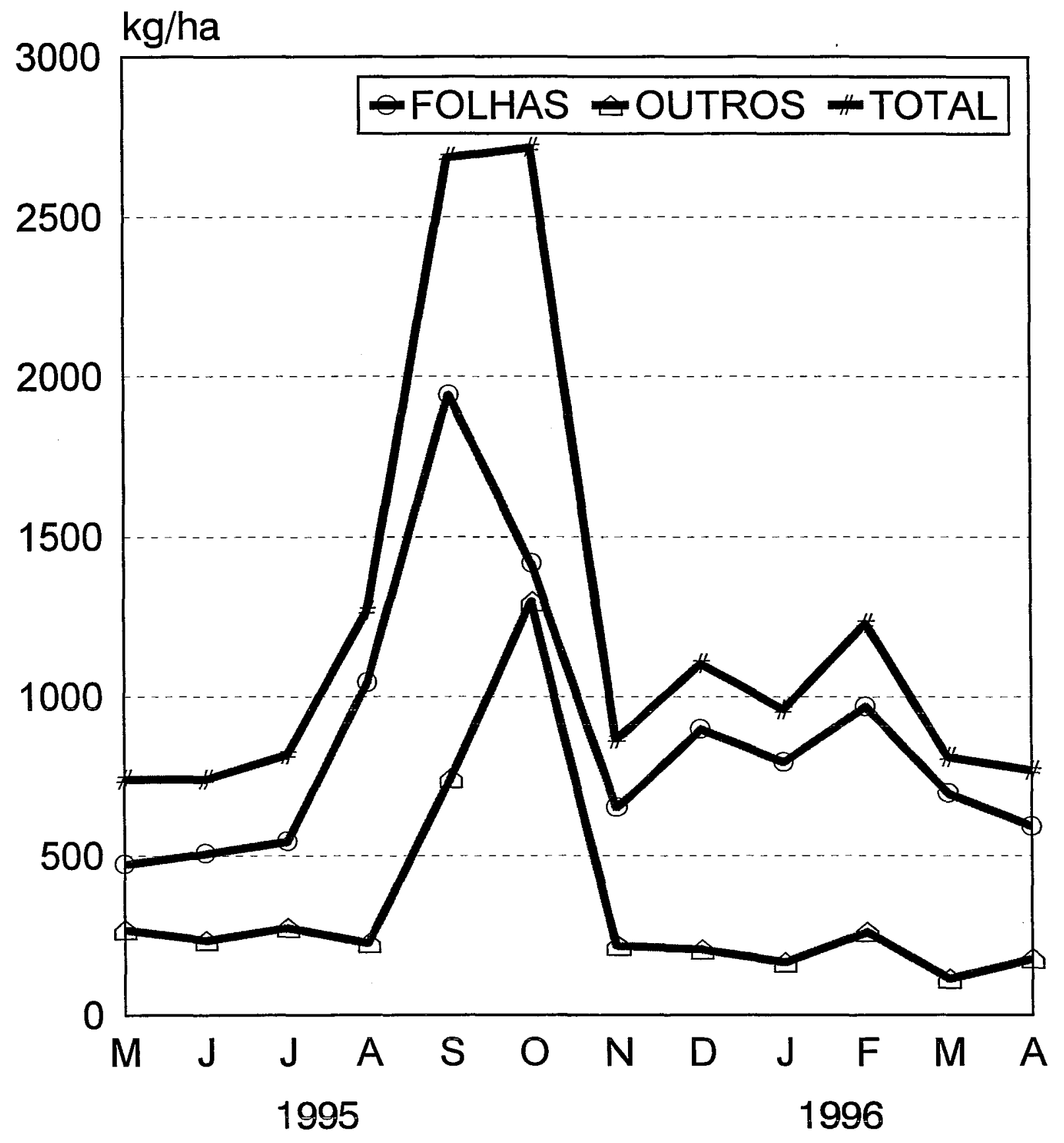

Figura 05: Produção total de serapilheira e suas frações. 
A queda de material vegetal também pode estar relacionada a fatores bióticos, como a sazonalidade e fenologia apresentadas pelas diferentes espécies. Pode depender da porcentagem de espécies decíduas na área estudada, períodos de floração, frutificação ou dispersão de sementes pelas espécies presentes. De acordo com a fase fenológica dessas espécies, vai ocorrer maior ou menor deposição das diferentes frações, como ramos, folhas, flores, frutos e sementes. A fração Folhas representou 71,58\% da biomassa depositada.

A deciduidade parece ser, em matas mesófilas semidecíduas, a causa de maior deposição de folhas na estação seca. Morellato (1992b), revisando outros autores, cita também a influência da deficiência hídrica, do fotoperíodo e da disponibilidade de nutrientes, entre outros.

Essa fração é sempre a fração dominante na produção de serapilheira. A porcentagem encontrada supera o padrão sugerido por Bray \& Gorham (1964), que era de $62 \%$, mas está bem próximo ao sugerido por Meentmeyer (1982), de 70\%.

As porcentagens encontradas por outros autores em outras áreas de mata mesófila no estado são inferiores a $67 \%$. A menor porcentagem foi encontrada por Pagano (1989a) de 62,03\%, e a maior por Diniz (1987), 66,32\%.

As duas frações estudadas apresentaram comportamento sazonal, porém com picos de deposição diferentes; a fração Folhas foi mais depositada em setembro (1941,85 kg.ha $\left.{ }^{-1}\right)$ e a fração Outros em outubro $\left(1298,87 \mathrm{~kg} \cdot \mathrm{ha}^{-1}\right)$.

De acordo com outros trabalhos, a fração Folhas acompanha o comportamento sazonal e mesmo determina as tendências das curvas de deposição total (César, 1993a; Pagano, 1989(a); Morellato, 1992(a), o que também pode ser observado nesse trabalho.

Em outubro, as duas frações apresentaram valores muito próximos, tendo os valores da fração Outros aumentado consideravelmente. Isso pode ser explicado pela ocorrência da tempestade em outubro, com ventos de grandes velocidades e chuva de granizo, que derrubou muito material lenhoso, inclusive de lianas, quase que superando a 
deposição foliar nesse mês. Zimmerman et al (1995) sugerem que a maneira pela qual a deposição de material lenhoso regula a função do ecossistema em diferentes florestas é significantemente afetado pelo regime de perturbação.

\subsection{3-Transferência de nutrientes através da serapilheira produzida e} eficiência de utilização de nutrientes

Vitousek \& Sanford (1986) enfatizam a ciclagem de nitrogênio, fósforo, potássio, cálcio e magnésio, e segundo os autores, são esses os nutrientes que principalmente limitam a produtividade primária e outras funções do ecossistema.

Sarruge \& Haag (1974) propõem alguns padrões para as concentrações desses nutrientes em plantas, de 0,1 a $1,5 \%$ da matéria seca para o fósforo, estando as mais comuns entre 0,1 e $0,3 \%$. As demais concentrações seriam de 1 a $5 \%$ para o nitrogênio, de 0,2 a $11 \%$ para o potássio, de 0,02 a $5 \%$ para o cálcio e de 0,02 a $2,5 \%$ para o magnésio.

A Tabela 13 demonstra as concentrações dos macronutrientes, no decorrer do ano de estudo, para ambas as frações analisadas.

As concentrações dos elementos mostraram-se bastante elevadas, tendo excedido a grande maioria, (senão todos para alguns nutrientes), dos dados citados até hoje na literatura.

As concentrações encontradas excedem os padrões propostos, menos as do nitrogênio, que se enquadram na média. As concentrações do fósforo, potássio, magnésio e principalmente cálcio surpreendem. O cálcio é o nutriente cujas concentrações são as mais altas, atingindo até $60 \mathrm{~g} \cdot \mathrm{kg}^{-1}$, em alguns dos meses estudados.

O retorno total estimado de macronutrientes foi de $1145,77 \mathrm{~kg} \cdot \mathrm{ha}^{-1}$. Esse valor é maior do que os encontrados para outras matas mesófilas semidecíduas do estado de São Paulo - vide Meguro et al (1979a); Diniz (1987); Pagano (1989) e César (1993b). 
Tabela 13: Concentração dos macronutrientes, nas duas frações analisadas, no decorrer do período de estudo $\left(\mathrm{g} \cdot \mathrm{kg}^{-1}\right)$ :

\begin{tabular}{|c|c|c|c|c|c|c|c|c|c|c|}
\cline { 2 - 12 } \multicolumn{1}{c|}{} & \multicolumn{2}{c|}{ N } & \multicolumn{2}{c|}{ P } & \multicolumn{2}{c|}{ K } & \multicolumn{3}{c|}{ Ca } & \multicolumn{3}{c|}{ Mg } \\
\cline { 2 - 12 } \multicolumn{1}{c|}{} & Folhas & Outros & Folhas & Outros & Folhas & Outros & Folhas & Outros & Folhas & Outros \\
\hline Mai & 17.64 & 15.93 & 0.91 & 0.97 & 8.4 & 4.1 & 54.6 & 48.9 & 6.1 & 2.75 \\
\hline Jun & 18.24 & 19.53 & 1.2 & 1.31 & 8.3 & 6.7 & 60.0 & 59.4 & 5.8 & 3.95 \\
\hline Jul & 20.09 & 19.6 & 1.48 & 1.14 & 7.6 & 4.6 & 61.5 & 54.3 & 4.8 & 3.3 \\
\hline Ago & 14.88 & 19.36 & 0.91 & 1.37 & 10.4 & 8.5 & 45.9 & 51.0 & 5.8 & 3.85 \\
\hline Set & 14.67 & 14.35 & 1.02 & 1.02 & 7.3 & 5.2 & 58.2 & 43.5 & 4.7 & 2.95 \\
\hline Out & 18.62 & 16.7 & 1.2 & 0.86 & 5.3 & 4.2 & 51.6 & 28.5 & 3.5 & 2.1 \\
\hline Nov & 17.96 & 17.99 & 1.14 & 1.14 & 7.8 & 6.0 & 50.7 & 41.7 & 4.1 & 3.1 \\
\hline Dez & 21.07 & 16.63 & 1.14 & 0.97 & 3.8 & 2.9 & 35.4 & 43.8 & 6.8 & 1.25 \\
\hline Jan & 18.8 & 15.65 & 1.2 & 1.03 & 10.5 & 6.1 & 39.3 & 42.9 & 5.1 & 3.0 \\
\hline Fev & 19.67 & 16.24 & 1.37 & 0.91 & 5.0 & 4.0 & 54.0 & 40.7 & 4.2 & 3.1 \\
\hline Mar & 22.12 & 21.67 & 1.26 & 1.37 & 9.3 & 6.1 & 43.5 & 48.3 & 5.3 & 4.05 \\
\hline Abr & 19.71 & 17.12 & 1.25 & 1.08 & 10.2 & 7.3 & 49.2 & 41.1 & 6.7 & 3.7 \\
\hline
\end{tabular}

Segundo Brown \& Lugo (1990), apesar de as chamadas florestas secundárias acumularem pequenas quantidades de nutrientes nas folhas, retornam grandes quantidades na queda desse material. Isso significa que o retorno de nutrientes na serapilheira é extremamente alto, devido à sua alta taxa de deposição em florestas secunndárias. A estratégia para ciclagem de nutrientes nesses ecossistemas parece ser o rápido acúmulo na vegetação e rápido retorno pela queda de serapilheira, provavelmente acompanhada por rápida reciclagem e absorção pelas raízes. Estes mesmos autores sugerem que a vegetação pioneira é menos conservativa com nitrogênio e cálcio, por exemplo, que uma vegetação mais madura. Sugerem também que florestas perturbadas aceleram o retorno de nutrientes, particularmente de fósforo, ao solo florestal.

O cálcio é o elemento que apresenta a maior transferência dentro da vegetação, $703,08 \mathrm{~kg} \cdot \mathrm{ha}^{-1}$. O retorno desse elemento é alto para a maioria das florestas tropicais estudadas, segundo Vitousek (1984). 
O total de transferência para os outros macronutrientes foi de $261,2 \mathrm{~kg} \cdot \mathrm{ha}^{-1} \mathrm{de}$ nitrogênio, 16,38 kg.ha ${ }^{-1}$ de fósforo, 100,19 kg.ha ${ }^{-1}$ de potássio e 64,86 kg.häde magnésio, valores esses também considerados altos.

O retorno dos macronutrientes na serapilheira encontra-se na seguinte ordem: $\mathrm{Ca}, \mathrm{N}, \mathrm{K}, \mathrm{Mg}$ e $\mathrm{P}$. Na maioria dos trabalhos desenvolvidos anteriormente em matas mesófilas, a seqüência era de N, Ca, K, Mg e P (como em Pagano, 1989; César, 1993; Meguro et al, 1979a, entre outros). Num estudo realizado por Diniz (1987) os teores de cálcio foram superiores aos do nitrogênio, nos ramos, flores e frutos, embora não tão discrepantes. A quantidade de nitrogênio superou a de cálcio nas folhas.

A variação entre locais é esperada (Tabela 14), devido a diferenças em suas características físicas, climáticas e biológicas, que afetam os padrões de ciclagem de nutrientes nos diversos ecossistemas.

Os padrões de ciclagem de nutrientes diferem em relação ao tipo de solo. Solos moderadamente férteis suportam florestas que ciclam grandes quantidades de nutrientes. Florestas em solos mais pobres ciclam quantidades menores de fósforo e cálcio, embora aparentemente pareçam ricas em nitrogênio (Vitousek \& Sanford, 1986).

Pagano (1989), baseando-se na alta fertilidade do solo e baixa eficiência de utilização de nutrientes em sua área de estudo, sugeriu que altas taxas de macronutrientes retornando ao solo florestal indicam ausência de mecanismos de conservação para esses elementos por parte da vegetação. César (1993) porém, afirma que a manutenção dos ecossistemas de mata mesófla semidecídua depende muito mais do retorno de matéria orgânica do que da fertilidade do solo.

Diferentes teores dos diferentes nutrientes, no decorrer do período de estudo podem ocorrer em conseqüencia ou sob influência de diversos fatores. 
A estrutura e composição de espécies da vegetação afetam os padrões de queda de serapilheira e de nutrientes. Algumas espécies tem maior ou menor capacidade de ciclagem de alguns nutrientes do que outras. Os aspectos fenológicos das espécies presentes e da comunidade como um todo causam variações na deposição dos nutrientes no decorrer do ano; fazendo com que haja ou não uma maior ou menor sazonalidade nos padrões de deposição. Por exemplo: a maior ou menor ocorrência de espécies decíduas pode ocasionar, nos meses de maior queda de folhas (meses mais secos), aumentos na deposição de alguns nutrientes.

As diferentes frações da serapilheira contêm concentrações diferentes de nutrientes. No estudo realizado por Luizão (1989), a maior concentração de Ca estava no material lenhoso, e as de $\mathrm{P}$ e $\mathrm{K}$ nas estruturas reprodutivas.

Neste estudo, o retorno dos macronutrientes ao solo nas diferentes frações apresentou uma certa sazonalidade, embora não coincidente com a deposição de serapilheira total (Figuras 06 a 11). O cálcio foi mais depositado em setembro e em fevereiro, acompanhando o comportamento da fração Folhas. A explicação para a maior transferência de $\mathrm{Ca}$ coincidente com os picos da queda de folhedo devem-se às maiores concentrações dese elemento na fração Folhas que na fração Outros.

O comportamento do nitrogênio foi semelhante à da fração Outros, com produção máxima em outubro. Houve semelhança no retorno do nitrogênio nos meses de dezembro e fevereiro, ambos meses relativamente chuvosos. Muito do material foliar derrubado pela tempestade em outubro ainda estava verde, provavelmente explicando uma alta produção do nitrogênio nesse mês.

Os demais macronutrientes apresentaram comportamento semelhante, com pico de deposição em setembro, com exceção do fósforo, que foi em outubro. $O$ segundo pico de deposição do magnésio foi em dezembro, o do potássio em janeiro e o do fósforo em setembro. 

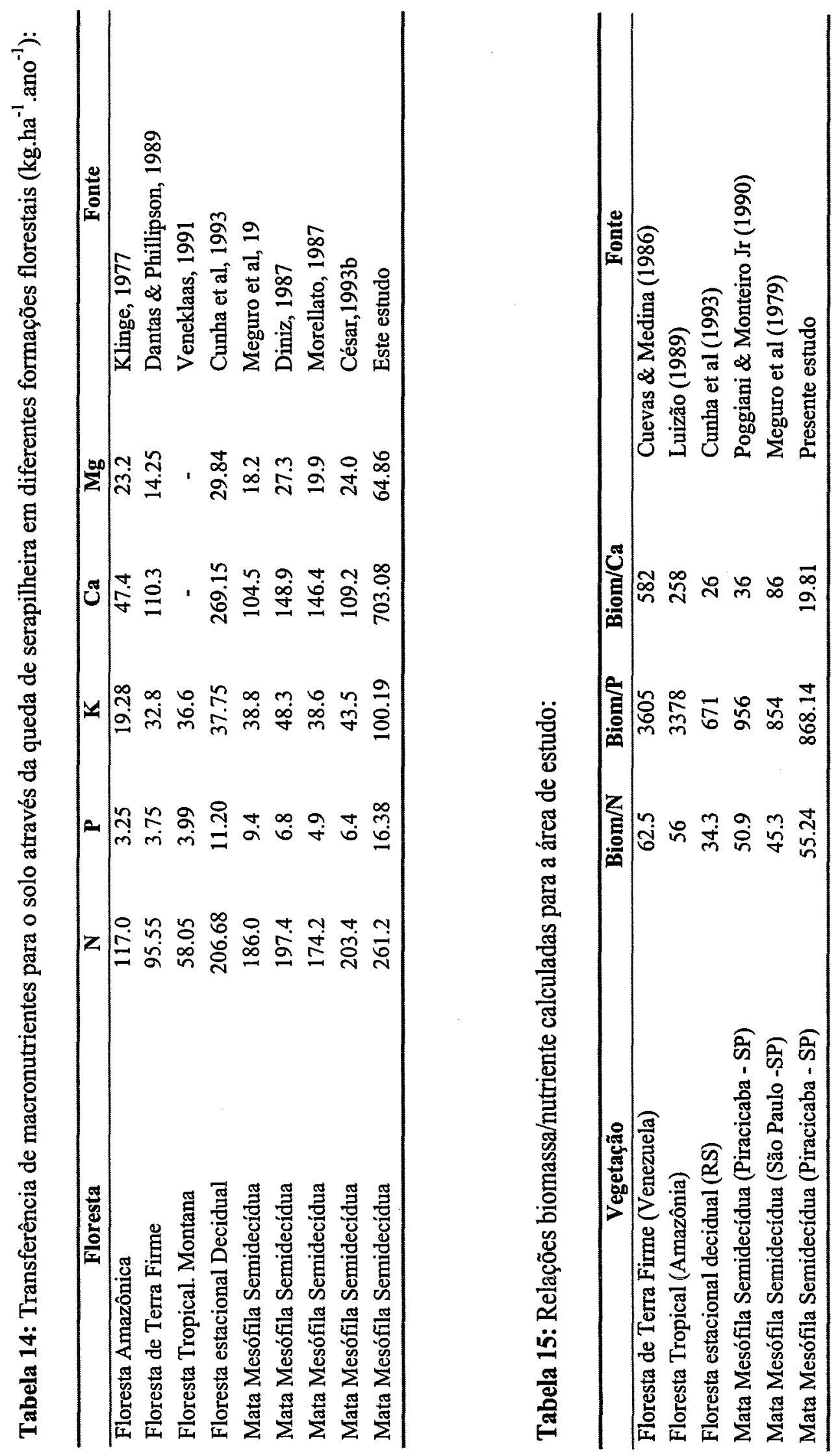
A presença de diversas espécies de lianas pode estar favorecendo a transferência de alguns nutrientes, embora não tenham sido realizadas análises químicas diferenciadas nas diferentes espécies de árvores, arbustos e lianas na área de estudo. A deposição de grandes quantidades de folhas e material lenhoso por essas plantas pode aumentar o retorno de alguns nutrientes.

Considerando que o fragmento encontra-se em área de baixada, os altos teores de nutrientes na área muito provavelmente estão associados às práticas culturais realizadas no entorno, já que a área de estudo, como já descrito, é cercada por áreas utilizadas para agricultura, que sofrem preparo de solo e adubações durante uma parte do ano.

Certamente, durante o período de estudo foram realizadas adubações em algumas áreas; e calagens pode ser responsáveis pelas concentrações excessivas encontradas para o cálcio no material coletado. Cabe ressaltar que a lavagem desses elementos cedidos pela adubação é extremamente favorecida pela declividade existente na área, que drena a água das chuvas para o interior do fragmento.

Cabe ressaltar que esta é uma situação muito comum, enfrentada pela grande maioria dos fragmentos existentes em propriedades agrícolas no estado de São Paulo. A maioria dos proprietários de terras não têm qualquer preocupação com a manutenção $\mathrm{e}$ proteção dos remanescentes florestais em suas propriedades. A maioria desses fragmentos tem sua dinâmica e sobrevivência comprometidos pelas diversas atividades realizadas no seu entorno, como fogo, preparo de solo, adubações e correções de fertilidade, entre outras.

Vitousek (1982) propôs a relação entre a biomassa de serapilheira produzida e a quantidade de nutrientes transferidos por ela como um índice de eficiência de utilização de nutrientes em um determinado local.

Segundo Brown \& Lugo (1990), essa relação é útil para a compreensão desse aspecto na dinâmica de nutrientes em ecossistemas florestais. 
A Tabela 15 mostra os índices de eficiência de $\mathrm{N}, \mathrm{P}$ e Ca para o fragmento estudado e outros tipos de vegetação.

Os resultados mostram uma relação biomassa/nitrogênio condizente com os valores econtrados na literatura, portanto a utilização desse nutriente pode ser considerada eficiente.

Segundo Vitousek (1982) ecossistemas florestais sistematicamente produzem mais massa seca de serapilheira por unidade de $\mathrm{N}$ em locais onde a circulação desse elemento acima do solo é menor. As diferenças entre os locais estão provavelmente ligadas a diferenças na disponibilidade de $\mathrm{N}$ no solo.

A eficiência de utilização do fósforo pode ser considerada baixa com relação à encontrada em florestas mais úmidas, porém, quando comparada a outras florestas com características deciduais, esse valor demonstra um eficiência de utilização razoável para esse elemento. Brown \& Lugo (1990) afirmam que a relação biomassa/nutriente tende a ser maior em florestas mais úmidas, para todos os elementos.

A utilização do cálcio é muito pouco eficiente, em contraste com os teores relativamente altos desse elemento no solo. O retorno de cálcio através da serapilheira foi extremamente alto, por volta de $60 \%$ de matéria seca total dos nutrientes analisados. A relação empregada mostra que a eficiência de utilização em florestas é maior quanto menor for a circulação do nutriente na serapilheira (Cuevas \& Medina, 1986).

Segundo Brown \& Lugo (1990), as florestas secundárias são em geral menos eficientes que as mais maduras, independentemente da idade, tipo de solo ou histórico de perturbação.

Isso ocorre porque a produtividade primária líquida ou taxa de crescimento é muito maior nas florestas secundárias, o que faz com que a absorção de nutrientes seja alta; entretanto, a biomassa acumulada é menor, e portanto a relação biomassa/nutriente é mais baixa nesse tipo de vegetação. 
Figura 06: Total de N e Ca transferidos pela fração Folhas

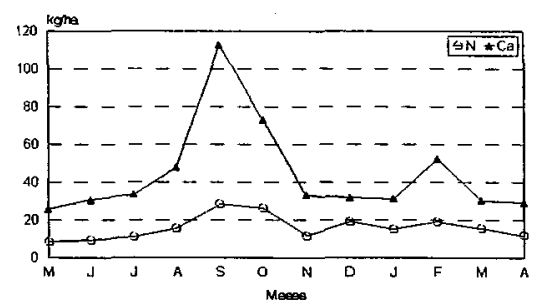

Figura 07: Total de $\mathrm{P}, \mathrm{K}$ e Mg transferidos pela fração Folhas

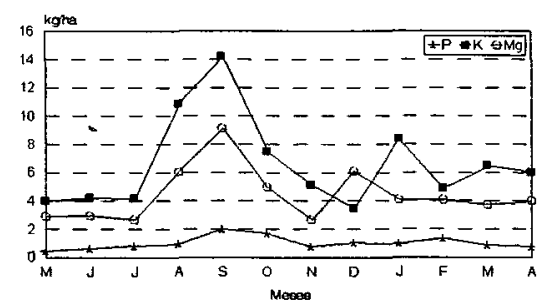

Figura 08: Total de N e Ca transferidos pela fração Outros

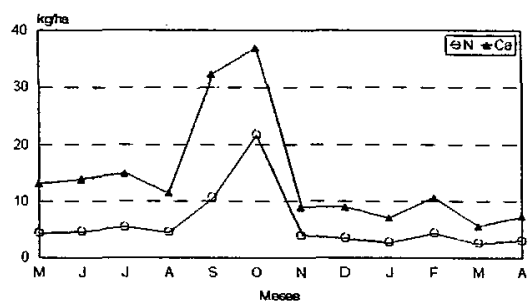

Figura 09: Total de $\mathrm{P}, \mathrm{K}$ e Mg transferidos pela fração Outros

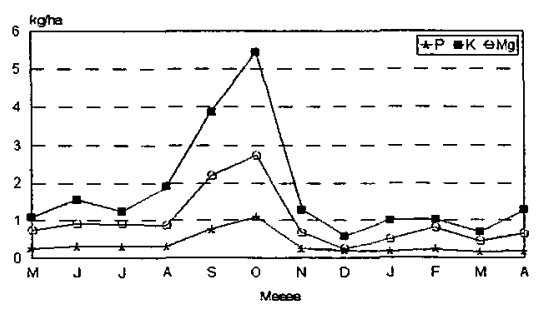

Figura 10: Total de N e Ca transferidos pela Serapilheira

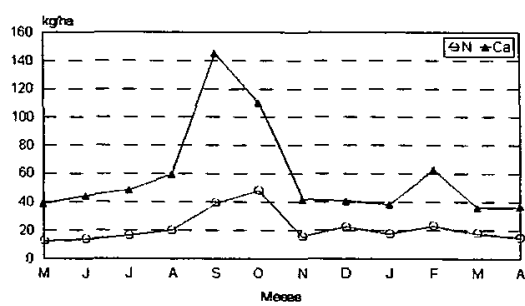

Figura 11: Total de $\mathrm{P}, \mathrm{Ke} \mathrm{Mg}$ transferidos pela Serapilheira

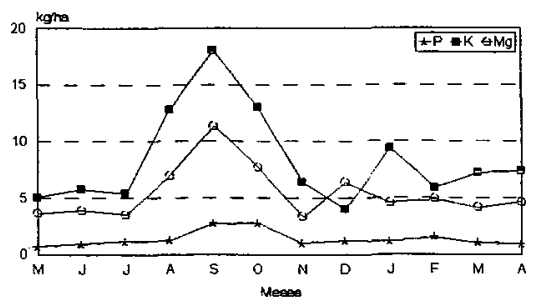


Com relação à conservação dos nutrientes, Brown e Lugo (1990) afirmam ainda que, aparentemente, a vegetação pioneira é menos conservativa para o $\mathrm{P}$ e tão conservativa para $\mathrm{N}$ e Ca quanto a vegetação mais madura.

\subsection{4-Serapilheira acumulada e taxa de decomposição}

No âmbito do estudo da ciclagem de nutrientes, a produção de folhedo e o processo de decomposição constituem parte importante da trajetória dos elementos no setor biológico e seu ambiente imediato: compartimento planta-folhedo-solo (Meguro et al, 1979). Assim, a investigação da decomposição é um aspecto importante da análise das funções do ecossistema (Wieder \& Lang, 1982).

Muita matéria orgânica é produzida e decomposta durante os primeiros anos de desenvolvimento da floresta. $\mathrm{O}$ impacto das florestas secundárias na matéria orgânica e na fertilidade do solo parece ser mais intensa durante esse período, decrescendo com o tempo (Brown \& Lugo, 1990).

A estimativa da serapilheira acumulada vai depender da época do ano. No presente estudo as coletas para obter essa estimativa foram feitas em duas épocas, uma durante a época seca e outra durante a época chuvosa. Golley (1983) afirma que as taxas de decomposição são baixas na estação seca e rápidas durante a úmida. Segundo César (1993), a taxa de decomposição é menos acentuada durante o inverno, ocasião em que a temperatura e o suprimento hídrico são menores.

A média anual de serapilheira acumulada foi de $7.745,43 \mathrm{~kg} \cdot \mathrm{ha}^{-1}$, e a constante de decomposição (K) 1,9 (Tabela 16).

Num estudo realizado por Vogt et al (1986), florestas decíduas apresentam menos matéria orgânica acumulada e tempo de residência menor da matéria orgânica no chão da floresta. Os fatores climáticos tiveram influência significativa na queda de serapilheira sobre o solo em florestas decíduas e sempre verdes. 
Pagano (1989) considera alto o valor de 1,15 para a constante K. Outros autores encontraram valores ainda mais altos em seus trabalhos. Morellato (1992) encontrou uma constante de 1,6. Poggiani \& Monteiro Jr.(1990) numa mata mesófila semidecídua muito próxima à area desse estudo, estimou $\mathrm{K}=2,3$, considerando apenas a fração folhas, sendo esse o maior valor até então.

Apesar de alto, o valor encontrado para a constante de decomposição (K) está dentro dos valores que, segundo Anderson \& Swift (1983) são comuns para florestas em regiões neotropicais, ou seja, entre 1 e 2. Já Olson (1963) afirma que valores de K para florestas tropicais variam de 1 a 4 .

Tabela 16: Valores de K (constante de decomposição) para ecossistemas florestais

\begin{tabular}{lcl}
\hline \multicolumn{1}{c}{ Tipo de floresta } & K & \multicolumn{1}{c}{ Fonte } \\
\hline Floresta montana (Venezuela) & 0.18 & Fassbender \& Grimm, 1981 \\
Fta. estacional decidual (RS) & 1.16 & Cunha et al, 1993 \\
Mata mesófila semidecídua & 0.86 & Meguro et al, 1979 \\
Mata mesófila semidecídua & 1.4 & Diniz, 1987 \\
Mata mesófila semidecídua & 1.15 & Pagano, 1989 \\
Mata mesófila semidecídua & $2.3 *$ & Poggiani \& Monteiro Jr, 1990 \\
Mata mesófila semidecídua & 1.6 & Morellato, 1992 \\
Mata mesófila semidecídua & 1.06 & César, 1993 \\
Mata mesófila semidecídua & 1.9 & Presente estudo \\
\hline
\end{tabular}

César (1993) sugere que, as variações observadas nos padrões de decomposição entre os diversos ecossistemas, ocorram em função da cobertura vegetal, da produção e qualidade da serapilheira, das condições climáticas e da composição da microbiota e da mesofauna.

Anderson \& Swift (1983) enumeram vários fatores que podem explicar taxas diferentes de decomposição em florestas tropicais: baixa concentração de nutrientes, alta concentração de lignina nas folhas, atividade reduzida da fauna decompositora, etc... Pagano (1989) cita ainda o grau de intensidade de atividade antrópica e a localização dos ecossistemas. 
As taxas de decomposição podem ainda ser afetadas por técnicas de manejo (Kirmse et al, 1987), pelas características da vegetação, se esclerófila, decídua, etc (Van Wesemall, 1993), pela sazonalidade na umidade (Wieder \& Wright, 1995), e por vários fatores climáticos, como umidade relativa, precipitação, temperatura máxima, etc (Thaiutsa \& Granger, 1979).

A liberação de nutrientes pela decomposição também varia. Attwill (1968) em floresta de eucalipto encontrou a seqüência $\mathrm{K}>\mathrm{Ca}>\mathrm{Mg}>\mathrm{P}$, e afirma que esta pode ser explicada pelo comportamento desses elementos em termos de sua mobilidade dentro da biomassa e da lixiviação pelo dossel. Lisanework \& Michelsen (1994) encontraram K> $\mathrm{Mg}>\mathrm{Ca}>\mathrm{P}$ numa floresta da Etiópia.

Altos valores para a constante $\mathrm{K}$, segundo Pagano (1989a), sugerem um rápido reaproveitamento de nutrientes por parte da vegetação. $O$ autor afirma que isso parece característico para matas mesófilas semidecíduas no estado de São Paulo.

Alguns estudos recentes sugerem que em algumas florestas tropicais, onde decompositores e plantas competem por nutrientes limitantes, flutuações ambientais e os pulsos de nutrientes liberados podem ser necessários para manter altas taxas de mineralização de nutrientes, absorção pelas plantas e produtividade da floresta (Lodge et al, 1994).

Os valores calculados para o tempo médio de renovação da quantidade de serapilheira acumulada sobre o solo, e o tempo necessário para o desaparecimento de $50 \%$ e $95 \%$ da serapilheira, segundo metodologia de Shanks \& Olson (1961) encontramse na Tabela 17.

Tabela 17: Taxa de decomposição $(\mathrm{K})$, tempo médio de renovação $(1 / \mathrm{K})$ e tempo necessário para decomposição de $50 \%$ e $95 \%$ da serapilheira.

\begin{tabular}{cccc}
\hline Coeficiente de decomposição (K) & $1 / \mathrm{K}$ (anos) & $\mathrm{T} 0,5$ (anos) & $\mathrm{T} 0,05$ (anos) \\
\hline 1,9 & 0,53 & 0,36 & 1,58 \\
\hline
\end{tabular}


O tempo necessário para o desaparecimento de $50 \%$ e $95 \%$ da serapilheira foi, respectivamente, de 131 e 576 dias; confirmando taxas de decomposição mais rápidas na área estudada. César (1993a) encontrou 238 dias, e Pagano (1989a), 219 dias para a decomposição de $50 \%$ do material coletado.

Num estudo realizado por Herrera et al (1991), numa floresta tropical submontana em Cuba, os autores relacionam aspectos como as taxas de decomposição e ciclagem de nutrientes aos diferentes estádios silvigenéticos da floresta. Parece claro que o material das espécies presentes nas fases iniciais (eco-unidades mais jovens) apresentam taxas decomposição muito mais rápidas.

No fragmento estudado, como já descrito pela análise silvigenética, ocorrem altas porcentagens de eco-unidades em início de desenvolvimento, o que também pode estar contribuindo com as altas taxas de decomposição (K) encontradas. 


\section{5- CONSIDERAÇÕES FINAIS}

O tamanho da área utilizada para a análise silvigenética mostrou-se adequado, amostrando todos os tipos de eco-unidades localmente possíveis; e representando de uma forma bastante significativa o estado em que se encontra a vegetação presente em toda a área de estudo. A distância utilizada entre as linhas para o mapeamento das projeções de copa das árvores dominantes também foi adequada, mostrando pouca sobreposição das mesmas.

De acordo com os resultados obtidos pela análise silvigenética, pode-se concluir que a comunidade estudada não apresenta estabilidade. Trata-se de uma floresta bastante perturbada, o que pode ser visualizado pelas excessivas porcentagens de eco-unidades em reorganização e equilíbrio dinâmico do tipo $1 \mathrm{~A}$; e baixas porcentagens de eco-unidades do tipo $2 \mathrm{~A}$, equivalentes à fase mais madura da floresta.

A floresta demonstra ter sofrido graves perturbações num período relativamente recente, em parte por ocorrência de fogo, como consta em seu histórico, e, muito provavelmente também por extração seletiva de madeira.

Outras características descritas confirmam o grau de perturbação na dinâmica dessa comunidade, como o alto grau de infestação por lianas, uma ocorrência significativa de árvores mortas ou com seu modelo arquitetural inicial bastante alterado, e altura máxima do dossel reduzida.

A deposição de material vegetal (produção de serapilheira) também demonstra ter sido afetada por distúrbios. Insere-se aqui a alta deposição de material vegetal ocasionado pelas lianas. Cabe também lembrar que já foi demonstrado que a produção de biomassa (produtividade primária) pela vegetação é maior em seus estádios iniciais de desenvolvimento. No mosaico obtido pela análise silvigenética, nota-se que $21,7 \%$ da área é tomada por eco-unidades em início de desenvolvimento, e $26,98 \%$ por eco-unidades descritas por Torqueabiau (1986) como sendo 
possivelmente resultantes de distúrbios no dossel. Sendo assim, é esperada uma alta produtividade, e conseqüentemente, uma alta deposição de material sobre o solo nas condições apresentadas.

Como já foi colocado no desenvolvimento do presente estudo, parece clara a influência das atividades da vizinhança - principalmente da adubação- sobre a ciclagem de nutrientes na área estudada, que se reflete nos altos teores de nutrientes minerais retornando ao solo, num período relativamente curto, e eficiência de utilização muito baixa para alguns nutrientes.

O fragmento estudado, conforme já foi descrito, cobre área de nascentes e circunda um curso d'água, sendo fundamental para a proteção da qualidade da água dentro da propriedade, e num âmbito mais geral, da qualidade da água do Rio Piracicaba.

Cabe ressaltar a importância desses remanescentes de mata mesófila também no estado de São Paulo como um todo, como os últimos detentores da biodiversidade local.

Considerando tudo o que foi colocado sobre o deficiente estado de conservação do fragmento estudado, cabem algumas propostas para um manejo mais adequado da área, como:

- Determinar, através de levantamentos no campo, quais as espécies de lianas presentes na área que se encontram em desequilíbrio (ou seja, quais as espécies que realmente estão dificultando o desenvolvimento da floresta) e executar um corte seletivo brando de cipós, se realmente necessário;

- Utilizar práticas que minimizem o efeito de borda, como a implantação de uma "zona tampão", ao redor do fragmento estudado, utilizando plantio de espécies nativas de rápido crescimento; 
- Aumentar a proteção contra fogo, com a delimitação de aceiros ao redor de todo o fragmento;

- Redirecionamento do escoamento superficial, nas áreas agrícolas e ao redor da mata, a fim de se eliminar o impacto de irrigação e fertilizações executadas nas áreas vizinhas, e combater a erosão laminar;

- Executar, eventualmente, plantios de enriquecimento no interior do fragmento. Determinar espécies prioritárias através de levantamento fitossociológico e de estudos sobre a regeneração no local);

- Combate a espécies invasoras (gramíneas e outros grupos) que já começam a invadir o fragmento em questão. A regeneração em fragmentos de mata mesófila no estado encontra-se seriamente prejudicada devido ao desenvolvimento dessas espécies. 


\section{REFERÊNCIAS BIBLIOGRÁFICAS}

ANDERSON, J.M. \& SWIFT, M.J. Decomposition in tropical forests. In: Sutton, S.L.; Whitmore, T.C. \& Chadwick, A.C. (eds) Tropical Rain Forest: ecology and management. London: Blackwell Scientific Publications, 1983. p.287-309.

ARCOVA, F.C.S. Deposição e ciclagem dos nutrientes Ca, $\mathbf{M g}$ e $\mathbf{K}$ em ecossistemas florestais. (Seminário não publicado) 1993. $17 \mathrm{p}$.

ATTIWILL, P.M. The loss of elements from decomposing litter. Ecology, 49(1): 142$45,1968$.

BONILLA, D. \& RODÀ, F. Nitrogen cycles responses to disturbance: trenching experiments in an evergreen oak forest. In: Harrison, A.F. \& HEAL, O.W. (eds) Nutrient cycling in terrestrial ecosystems- field methods, application and interpretation. Elsevier Applied Science, 1990. p.179-89.

BRAY, J.R. \& GORHAM, E. Litter productions in forests of the world. Adv. Ecol. Res., 2: 101-157, 1964.

BREEMEN, v. N.; HUTTL, R.F. (ed.); NILSSON, L.O. (ed.); JOHANSSON, U.T. Nutrient uptake and cycling in forest ecosystems Plant and soil, 168/169: 321-326, 1995.

BROKAW, N.V. Treefalls, regrowth and community structure in tropical forests In: PICKETT, S.T.A.; WHITE, P.S. (eds) The ecology of natural disturbance and patch dynamics. New York Academic Press, 1985. p. 53-65.

BROWN, S. \& LUGO, A.E. Tropical secondary forests. Journal of Tropical Ecology, 6: $1-32,1990$.

BROWN,S. \& LUGO, A.E. The storage and production of organic matter in tropical forests and their role in the global carbon cycle. Biotropica, 14(3): 161-187, 1982.

BUDOWSKI, G. Forest sucession in tropical lowlands. Turrialba, 13(1):42-44, 1963.

BUDOWSKI, G. Distribution of tropical american rain forest species in the light of sucessional processes. Turrialba, 15(1):40-42, 1965.

BURGHOUTS, T.B.A.; CAMPBELL, E.J.F.; KOLDERMAN, P.J. Effects of tree species heterogeneity on leaf fall in primary and logged dipterocarp forest in the Ulu Segama Forest Reserve, Sabah, Malaysia. Journal of Tropical Ecology, 10:1-26, 1994. 
BURNHAM, R.J. Patterns in tropical leaf litter and implication for angiosperm paleobotany. Review of Paleobotany and Palynology, 81(1): 99-113, 1994.

CATHARINO, E.L.M. Estudos fisionômicos, florísticos, e fitossociológicos em matas residuais secundárias no município de Piracicaba-SP. Campinas,1989. 181p. Dissertação de mestrado- Instituto de Biologia/ UNICAMP.

CÉSAR, O. Produção de serapilheira na mata mesófila semidecídua da Fazenda Barreiro Rico, município de Anhembi, SP. Revista Brasileira de Biologia, 53(4):671-681, 1993(a).

CÉSAR, O. Nutrientes minerais na serapilheira produzida na mata mesófila semidecídua da Fazenda Barreiro Rico, município de Anhembi, SP. Revista Brasileira de Biologia, 53(4):659-669, 1993(b).

CORNEJO, F.H.; VARELA, A.; WRIGHT, S.J. Tropical forest litter decomposition under seasonal drought: nutrient release, fungi and bacteria. Oikos, 70(2): 183-190, 1994.

COSTA, L.G.S. Estrutura e dinâmica de trecho de mata mesófila semidecídua na Estação Ecológica de Ibicatu, Piracicaba - SP São Paulo, 1992, 200 p. Dissertação de mestrado- Instituto de Biociências - USP.

CUEVAS, E. \& MEDINA, E. Nutrient dynamics within amazonian forest ecosystems Inutrient fluxe in fine litter fall and efficiency of nutrient utilization. Oecologia, 68: 466-72, 1986.

CUNHA, G.C.; GRENDENE, L.A.; DURLO, M.A.; BRESSAN, D.A. Dinâmica nutricional em floresta estacional decidual com ênfase aos minerais provenientes da deposição da serapilheira. Ciência Florestal, 3(1): 35-64, 1993.

DANTAS, M. \& PHILLIPSON, J. Litterfall and nutrient content in primary and secondary amazoniam "terra firme" rain forest. Journal of Tropical Ecology, 5: 2736, 1989.

DELITTI, W.B.C. Aspectos dinâmicos da serapilheira de uma floresta implantada de Pinus elliotti Englm. var elliotti (Mogi Guaçu - SP) São Paulo, 1982. 137 p. Dissertação de mestrado. Instituto de Biociências/USP.

DELITTI, W.B.C. Ciclagem de nutrientes em matas ciliares. Silvicultura em São Paulo, 16A(único): 88-98, 1982. 
DENSLOW, J.S. Gap partioning among tropical rainforest trees. Biotropica, 12(2):47$55,1980$.

DENSLOW, J.S. Tropical rainforest gaps and tree species diversity. Annual Review of Ecology and Systematics, 18: 431-51, 1987.

DINIZ, S. Ciclagem de nutrientes associados aos processos de produção e decomposição do folhedo em um ecossistema de mata mesófila semidecídua no município de Araras, SP, Brasil Rio Claro, 1987. 93 p. Dissertação de mestradoUNESP/Rio Claro.

ENGEL, V.L. 1993 O papel de lianas na dinâmica de crescimento e regeneração de comunidades de florestas tropicais. (Manuscrito, não publicado), 1993. 24 p.

ENGEL, V.L. 1993 Silvigênese, dinâmica de fragmentos e a conservação de florestas tropicais. Série Florestal FEPAF 1(1), 21 p.

ENGEL, V.L.\& PRADO, P.T.K.L. Aspectos da silvigênese de uma mata pluvial atlântica em Linhares, ES. Revista do Instituto Florestal, 4 (único), 163-68, 1992.

FASSBENDER, H.W. \& GRIMM, U. Ciclos bioquímicos en un ecosistema forestal de los Andes Occidentales de Venezuela II- Producción y descomposición de los residuos vegetales. Turrialba, 31(1): 39-47, 1981.

GERMAN BUNDESTAG (ed) Protecting the tropical forests - a high priority international task. Bonn: Deutscher Bundestag, 1990. $968 \mathrm{p}$.

GIULETTI, A.M. Biodiversidade na Região Sudeste. Revista do Instituto Florestal, 4 (único): 125-130, 1992.

GOLLEY, F.B. Ciclagem de nutrientes em um ecossistema de floresta tropical úmida São Paulo: EPU-EDUSP, 1975. 256 p.

GOLLEY, F.B. Tropical Rain Forest Ecosystems: structure and function. Amsterdan: Elsevier, 1983. 392p.

HAAG, H.P. Ciclagem de nutrientes em florestas tropicais. Campinas: Fundação Cargill, 1985. $154 \mathrm{p}$.

HALLÉ, OLDEMAN, R.A.A. \& TOMLINSON, P.B. Tropical trees and forests: an architectural analysis. Berlin: Springer-Verlag, 1978. $441 \mathrm{p}$.

HARRIS, L.D. The fragmented forest: island biogeography theory and the preservation of biotic diversity. Chicago: University of Chicago, 1984. 229 p. 
HARTSHORN, G.S. Neotropical rainforest dynamics. Biotropica, 12(2):23-30, 1980. HEGARTY, E.E. Leaf litter production by lianes and trees in a sub-tropical Australian rain forest. Journal of Tropical Ecology, 7: 201-214, 1991.

HERBOHN, J.L. \& CONGDON, R.A. Ecosystem dynamics at disturbed and undisturbed sites in north Queensland wet tropical rain forest II- Litterfall. Journal of Ecology, 9: 365-380, 1993.

HERRERA, R.A.; CAPOTE, R.P., MENÉNDEZ, L.; RODRÍGUEZ, M.E. Silvigenesis stages and the role of mycorrhiza in natural regeneration in Sierra del Rosario, Cuba In: Gomez-Pompa, A.; Whitmore, T.C.; Hadley, M. Rain Forest Regeneration and Management MAB Series, v.6, Paris and the Parthenon Publishing Group. 1991. p.211-221.

IBGE Manual Técnico da Vegetação Brasileira. Rio de Janeiro: IBGE, $1992 . \quad$ p.

JORDAN; C.F. Nutrient cycling in tropical forest ecosystems: principles and their applications in management and conservation. Chichester: John Wiley and Sons, 1985. $200 \mathrm{p}$.

JORDAN, C.F. \& HERRERA, R. Tropical rain forests: are nutrient really critical? The American Naturalist, 117(2): 167-180,

KAGEYAMA, P.Y. \& GANDARA F.B. Dinâmica de populações de espécies arbóreas, implicações para o manejo e a conservação. In: III Simpósio de Ecossistemas da Costa Brasileira, 02 a 07/04/1994- Serra Negra, SP. Anais da Academia De Ciências do Estado de São Paulo e Academia Brasileira de Ciências, V.II, p. 1-9.

KAGEYAMA, P.Y. Conservação "in situ" de recursos genéticos de plantas. Revista IPEF, 35:7-37, 1987.

KIRMSE, R.D.; PROVENZA, F.D.; MALECHECK, J.C. Effects of clearcutting on litter production and decomposition in semiarid tropics of Brazil. Forest Ecology and Management, 22: 205-217, 1987.

KLINGE, H. Fine litter production and nutrient return to the soil in three natural forest stands of eastern Amazonia. Geo. Eco. Trop., 1(2): 159-167, 1977.

LAURANCE, W.F. Edge effects in tropical forest fragments: application of a model for the design of natural reserves. Biological Conservation, 57(2): 205-219, 1991. 
LEITÃO FILHO, H.F. Aspectos taxonômicos das florestas do estado de São Paulo. Silvicultura em São Paulo, 16A (Parte I, ed. especial): 197-206, 1982.

LEITÃO FILHO, H.F. Considerações sobre a florística de florestas tropicais e subtropicais do Brasil. Revista IPEF, 35: 41-47, 1987.

LISANEWORK, N. \& MICHELSEN, A. Litterfall and nutrient release by decomposition in three plantations compared with a natural forest in the Ethiopian highland. Forest Ecology and Management, 65: 149-164, 1994.

LODGE, D.J.; McDOWELL, W.L.; McSWINEY, C.P. The importance of nutrient pulses in tropical forests. TREE, 9(10): 384-387, 1994.

LUIZÃO, F.J. Litter production and mineral element input to the forest floor in a central amazonian forest. GeoJournal, 19(4): 407-417, 1989.

MARTINEZ-RAMOS, M. Claros, ciclos vitales de los arboles tropicales e regeneración natural de las selvas altas perennifolias. In: GOMEZ POMPA, A.; AMO, S.R. (eds) Investigaciones sobre la regeneración de selvas altas en Vera Cruz, Mexico. Mexico:INIRB Alhambra Mexicana, 1985. p. 191-240.

MEENTMEYER, V. World patterns and amounts of terrestrial plant litter production. BioScience, 32:125-128, 1982.

MEGURO, M.; VINUIZA, G.N; DELITTI, W.B.C. Ciclagem de nutrientes na mata mesófila secundária I- Produção e conteúdo de nutrientes minerais no folhedo. Boletim de Botânica da Universidade de São Paulo, 7: 11-31, 1979(a).

MEGURO, M.; VINUIZA, G.N; DELITTI, W.B.C. Ciclagem de nutrientes na mata mesófila secundária II- $\mathrm{O}$ papel da precipitação na importância e transferência de potássio e fósforo. Boletim de Botânica da Universidade de São Paulo, 7: 61-7, 1979(b).

MONTAGNINI, F. \& SANCHO, F. Nutrient budgets of young plantations with native trees: strategies for sustained management. In: BENTLEY, W. \& GOWEN, M. (eds) Forest resources and wood based biomass energy as rural development assets. New Delhi: Winrock International and Oxford \& IBH Publishing Co., 1994. p.213233.

MORELLATO, L.P.C. Nutrient cycling in two south-east brazilian forests I- Litterfall and litter standing crop. Journal of Tropical Ecology, 8:205-215, 1992(a). 
MORELLATO, L.P.C. Sazonalidade e dinâmica de ecossistemas florestais na Serra do Japi. In: Morellato, L.P.C. (ed) História natural da Serra do Japi- ecologia e preservação de uma área florestal no sudeste do Brasil. Campinas: UNICAMP, 1992(b). p.98-109.

ODUM, E.P Ecologia Rio de Janeiro: Ed. Guanabara, 1983. 431 p.

OLDEMAN, R.A.A. Architecture and energy exchange of dicotyledonous trees in the forest. In: TOMLINSON, P.B. \& ZIMMERMANN, M.H. Tropical trees as living systems. Cambridge: Cambridge Un. Prees, 1978. p. 535-61.

OLDEMAN, R.A.A. Quelques aspects quantifiables de l'arborigenèse et de la sylvigenèse. Oecol. Plant. Cedex, 14: 289-312, 1979.

OLDEMAN, R.A.A. Tropical rainforest, architecture, sylvigenesis and diversity. In: SUTTON, S.L.; WHITMORE, T.C.; CHADWICK, A.C. (eds) Tropical rainforest: ecology and management. Oxford: Blackwell Scientific, 1983. p.139-150.

OLDEMAN, R.A.A. On the limits of forest ecosystems: do they have skins? In: IUFRO World Congress, 18 Ljubljana Proceedings Ljubljana: Internacional Union of Forest Research Organizations, 312-24, 1986.

OLDEMAN, R.A.A. Forest ecology for silvicultural design. Local: Wageningen Agricultural University Press, 1987.640 p.

OLDEMAN, R.A.A. Dynamics in tropical rainforests. In: HOLM-NIELSEN, L.B.; NIELSEN, I.C. \& BALSLEV, H. Botanical dynamics, speciation and diversity. Academic Press, 1989. p.3-21.

OLDEMAN, R.A.A. Elements of silvology. Berlin, Heidelberg, New York: SpringerVerlag, 1990. $623 \mathrm{p}$.

OLSON, J.S. Energy storage and the balance of producers and decomposers in ecological systems. Ecology, 44(2): 322-331, 1963.

PACKHAM, J.R.; HARDING, D.J.L.; HILTON,G.M.; STUTTARD, R.A. Functional Ecology of Woodlans and Forests. London, Glasgow, New York,Tokyo, Melbourne, Masdras: Chapman \& Hall, 1992.

PAGANO, S.N. Estrutura florística, fitossociológica e de ciclagem de nutrientes em mata mesófila semidecídua no município de Rio Claro- SP. Rio Claro, 1985. 201 p. Tese de Livre Docência- IB/UNESP. 
PAGANO, S.N. Produção de folhedo em mata mesófila semidecídua no município de Rio Claro, SP. Revista Brasileira de Biologia, 49(3):633-639, 1989(a).

PAGANO, S.N. Nutrientes minerais no folhedo produzido em mata mesófila semidecídua no município de Rio Claro, SP. Revista Brasileira de Biologia, 49(3):641-647, 1989(b).

PICKETT, S.T.A. Differential adaptation of tropical tree species to canopy gaps and its role in community dynamics. Tropical Ecology (24): 68-84, 1983.

PIMENTEL-GOMES, F. \& CHAVES, R. A amostragem ótima em inventário florestal. Revista IPEF, (35): 17-22, 1988.

PIMENTEL-GOMES, F. \& COUTO, H.T.Z. O tamanho ótimo de parcela experimental para ensaios com eucaliptos. Revista IPEF, (31): 75-77, 1985.

POGGIANI, F. \& MONTEIRO JR 1990 Deposição de folhedo e retorno de nutrientes ao solo numa floresta estacional semidecídua, em Piracicaba (estado de SP). In: Anais do VI Congresso Florestal Brasileiro, Campos do Jordão, 1990.

POGGIANI, F. Alterações dos ciclos bioquímicos em florestas. Revista do Instituto Florestal, 4-(único): 143-147, 1992.

POTTER, C.S.; RAGSDALE, H.L.; BERISH, C.W. Resorption of foliar nutrients in a regenerating southern appalachian forest. Oecologia, (73): 268-271, 1987.

PRITCHETT, W.L. Properties and management of forest soils. New York: John Wiley and Sons, 1987. 500p.

PROCTOR, J. Tropical forest litterfall I- Problems of data comparison. In: Sutton, S.L.; Whitmore, T.C. \& Chadwick, A.C. (eds) Tropical Rain Forest: ecology and management. London: Blackwell Scientific Publications, 1983. p.267-73.

REIS, M.F. Decomposição em florestas tropicais (Apostila não publicada), 1984. 32 p.

RIBEIRO, J.F. Comparação da concentração de nutrientes na vegetação arbórea e nos solos de um cerrado e um cerradão no Distrito Federal, Brasil. Brasília, 1983. 87 p. Dissertação de mestrado-Universidade de Brasília.

SAMPAIO, E.V.S.B.; NUNES, K.S.; LEMOS, E.E.P. Ciclagem de nutrientes na mata de Dois Irmãos (Recife-PE) através da queda de material vegetal. Pesquisa Agropecuária Brasileira 23 (10): 1055-1061, 1988. 
SARRUGE, J.R. \& HAAG, H.P. Análise química em plantas. Piracicaba, ESALQ, $1974,56 \mathrm{p}$.

SCHLITTER, F.H.M.; DE MARINIS, G.; CÉSAR, O. Produção de serapilheira na floresta do Morro do Diabo, Pontal do Paranapanema-SP. Naturalia, 18:123-134, 1993.

SCHUGART, H.H. A theory of forest dynamics: the implication of forest succession models. Heideberg: Springer-Verlag, 1984. $278 \mathrm{p}$.

SCHUMACHER, M.V. Aspectos da ciclagem de nutrientes e do microclima em talhões de Eucalyptus camaldulensis, E. grandis e E. torelliana. Piracicaba, 1992. 104 p. Dissertação de mestrado-ESALQ/USP.

SHANKS, R. \& OLSON, J.S. First year breakdown of leaf litter in Southern Appalachian Forest Revista Science, v.134, p.194-195.

SILVA, M.F.F. \& LOBO, M.G.A. Nota sobre deposição de matéria orgânica em floresta de terra firme, várzea e igapó. Boletim do Museu Paraense "Emílio Goeldi’- Botânica, 56: 1-13, 1982.

SNEDAKER, S.C. Successional immobilization of nutrients and biologically mediated recycling in tropical forests. Tropical Succession, 16-22, 1980.

SPURR, S.H. \& BARNES, B.V. Forest ecology. New York: John Wiley and Sons, 1973. $687 \mathrm{p}$.

SWITZER, G.L. \& NELSON, L.E. Nutrient accumulation and cycling in Loblolly Pine (Pinus taeda L.) plantation ecosystems: the first twenty years. Soil Science Soc. Amer. Proc., 36: 143-147, 1972

SZOTT, L.T.; PALM, C.A.; DARVEY, C.B. Biomass and litter accumulation under managed and natural tropical fallows. Forest Ecology and Management, 67: 177190, 1994.

THAIUTSA, B. \& GRANGER, Climate and the decomposition rate of tropical forest litter Unasylva, 31:126, 28-35, 1979.

TILMAN, D. Constraints and tradeoffs: toward a predictive theory of competition and succession. Oikos, 58: 3-15, 1990.

TORQUEBIAU, E.F. Mosaic patterns in dipterocarp rainforest in Indonesia, and their implications for practical forestry. Journal of Tropical Ecology, 2:301-325, 1986. 
TORQUEBIAU, E.F. Photosynthetically active radiation environment, patch dynamics and architecture in a tropical rainforest in Sumatra. Australian Journal of Plant Physiology, 15: 327-42, 1988.

UHL, C.\& JORDAN, C.F. Succession and nutrient dynamics following forest cutting and burning in Amazonia. Ecology, 65(5): 1476-90, 1984.

VAN WESEMALL, B. Litter decomposition and nutrient distribution in humus profiles in some mediterranean forests in southern Tuscany. Forest Ecology and Management, 57: 99-114, 1993.

VENEKLAAS, E.J. Litterfall and nutrient fluxes in two montane tropical rain forests, Colombia. Journal of Tropical Ecology, 7: 319-336, 1991.

VIANA, V.M.; TABANEZ, A.J.A.; MARTINEZ, J.L.A. Restauração e manejo de fragmentos florestais Revista do Instituto Florestal, 4 (único): 407-412, 1992.

VIDAL-TORRADO, P. \& SPAROVEK, G. Mapa pedológico detalhado do Campus "Luiz de Queiroz", Universidade de São Paulo, Piracicaba (SP). - não publicado, 1993.

VITOUSEK, P.M. Nutrient cycling and nutrient use efficiency. American Naturalist, 119:553-572, 1982.

VITOUSEK, P.M. Litterfall, nutrient cycling and nutrient limitation in tropical forests. Ecology, 65(1): 285-298, 1984.

VITOUSEK, P.M. \& REINERS, W. Ecosystem succession and nutrient retention: a hypothesis. BioScience, 25 (6): 376-381, 1975.

VITOUSEK, P.M. \& SANFORD Jr, R.L. Nutrient cycling in moist tropical forest. Annual Review of Ecology and Systematics, 17: 137-167, 1986.

VOGT, K.A.; GRIER, C.C.; VOGT, D.J. Production, turnover and nutrient dynamics of above and belowground detritus of world forests Advances in ecological research, 15: 303-377, 1986.

WHITMORE, T.C. Gaps in the forest canopy. In: TOMLINSON, P.B. \& ZIMMERMANN, M.H. Tropical trees as living systems. Cambridge: Cambridge Un. Prees, 1976. p.639-649.

WIEDER, R.K. \& LANG, G.E. A critique of the analytical methods used in examining decomposition data obtained from litter bags. Ecology, 63(6): 1636-1642, 1982. 
WIEDER, R.K. \& WRIGHT, S.J. Tropical forest litter dynamics and dry season irrigation on Barro Colorado Island, Panama. Ecology, 76(6): 1971-79, 1995.

WRIGHT, S.J. \& CORNEJO, F.H. Seasonal drought and leaf fall in a tropical forest. Ecology, 71(3): 1165-75, 1990.

ZHANG, Q.H.; ZAK, J.C.; ZHANG, Q.H. Effects of gap size on litter decomposition and microbial activity in a subtropical forest. Ecology, 76(7): 2196-2204, 1995.

ZIMMERMANN, J.K.; PULLIAM, W.M.; LODGE, D.J.; QUIÑONES-ORFILA, V.; FETCHER, N.; GUZMÁN-GRAJALES, S.; PARROTTA, J.A.; ASBURY, C.E.; WALKER, L.R.; WAIDE, R.B. Nitrogen immobilization by decomposing woody debris and the recovery of tropical wet forest from hurricane damage. Oikos, 72: 314-322, 1995. 


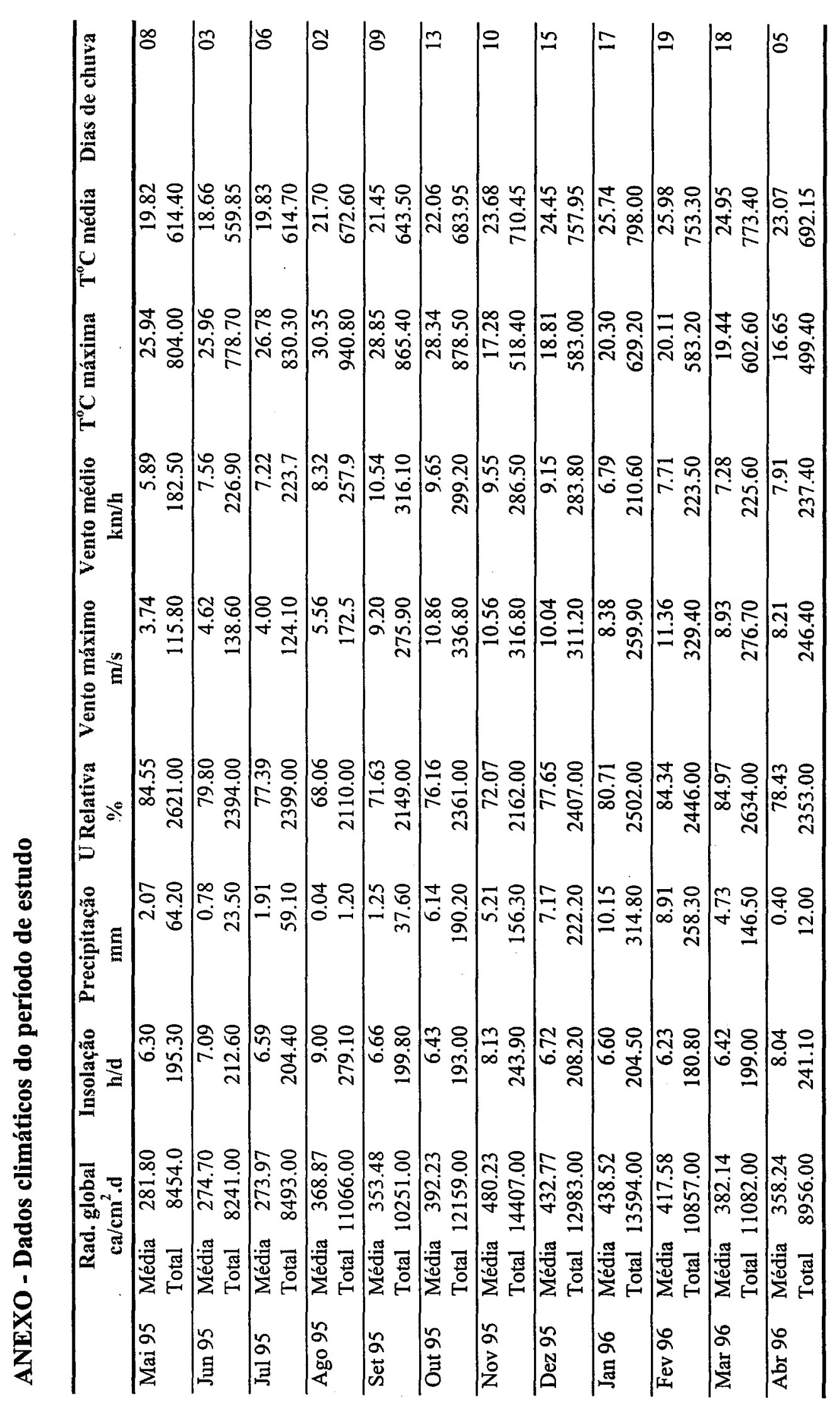

